\title{
The fossil history of pseudoscorpions (Arachnida: Pseudoscorpiones)
}

\author{
Danilo Harms ${ }^{1}$ and Jason A. Dunlop ${ }^{2}$ \\ ${ }^{1}$ University of Hamburg, Center of Natural History - Zoological Museum, Martin-Luther-King-Platz 3, \\ 20146 Hamburg, Germany \\ ${ }^{2}$ Museum für Naturkunde, Leibniz Institute for Evolution and Biodiversity Science, Invalidenstrasse 43, \\ 10115 Berlin, Germany
}

Correspondence to: Danilo Harms (danilo.harms@uni-hamburg.de)

Received: 21 April 2017 - Revised: 16 June 2017 - Accepted: 20 June 2017 - Published: 9 August 2017

\begin{abstract}
Pseudoscorpions, given their resemblance to scorpions, have attracted human attention since the time of Aristotle, although they are much smaller and lack the sting and elongated tail. These arachnids have a long evolutionary history but their origins and phylogenetic affinities are still being debated. Here, we summarise their fossil record based on a comprehensive review of the literature and data contained in other sources. Pseudoscorpions are one of the oldest colonisers of the land, with fossils known since the Middle Devonian (ca. 390 Ma). The only arachnid orders with an older fossil record are scorpions, harvestmen and acariform mites, plus two extinct groups. Pseudoscorpions do not fossilise easily, and records from the Mesozoic and Cenozoic consist almost exclusively of amber inclusions. Most Mesozoic fossils come from Archingeay and Burmese ambers (Late Cretaceous) and those from the Cenozoic are primarily from Eocene Baltic amber, although additional fossils from, for example, Miocene Dominican and Mexican ambers, are known. Overall, 16 of the 26 families of living pseudoscorpions have been documented from fossils and 49 currently valid species are recognised in the literature. Pseudoscorpions represent a case of morphological stasis and even the Devonian fossils look rather modern. Indeed, most amber fossils are comparable to Recent groups despite a major gap in the fossil record of almost 250 Myr. Baltic amber inclusions indicate palaeofauna inhabiting much warmer climates than today and point to climatic shifts in central Europe since the Eocene. They also indicate that some groups (e.g. Feaellidae and Pseudogarypidae) had much wider Eocene distributions. Their present-day occurrence is relictual and highlights past extinction events. Faunas from younger tropical amber
\end{abstract}

deposits (e.g. Dominican and Mexican amber) are comparable to Recent ones. Generally, there is a strong bias in the amber record towards groups that live under tree bark, whereas those from litter habitats are underrepresented. We also discuss challenges in interpreting fossils: their cryptic morphology warranting novel techniques of morphological reconstruction, the massive gap in the fossil record between the Palaeozoic and Mesozoic, and problems with the classification of (historically) old amber material. Finally, we discuss aspects of the palaeoecology and biology of the fossils compared with the Recent fauna, such as phoresy.

\section{Introduction}

Pseudoscorpions (Arachnida: Pseudoscorpiones) are a group of small arachnids, with body lengths typically around 2$8 \mathrm{~mm}$. As their name implies, they superficially resemble scorpions in having large chelate pedipalps, but unlike scorpions they lack the tail ending in a sting. Pseudoscorpions are commonly found in habitats such as leaf litter, moss, bird nests, or under bark. Several have become adapted to cave environments in which troglomorphic adaptations such as the loss of eyes, body pigment, and/or elongated appendages are frequent. Others are obligate commensals and spend their entire life in mammal or bird nests (Weygoldt, 1969; Turienzo et al., 2010). Some pseudoscorpion groups are phoretic and attach themselves to insects, birds, and mammals that are used as vectors for passive dispersion. The synanthropic and cosmopolitan Chelifer cancroides is also known as the book scorpion because it invades houses and can be found 
among old manuscripts in libraries where it hunts for book lice. Species of the common European genus Neobisium are sometimes called moss scorpions and are a typical element of the soil arthropod fauna. All pseudoscorpions are predators and generally feed on small invertebrates, primarily arthropods (Weygoldt, 1969; Muchmore, 1973). The more derived families have venom glands in their pedipalps, which they use to immobilise their prey. However, given their small size even the venomous species are completely harmless to humans. Roughly 3450 species (Harvey, 2011) are currently known from habitats all over the world except Antarctica, although most species occur in the tropics and subtropical regions. Several families are restricted today to tropical environments. This puts them fifth in terms of global arachnid diversity, after the spiders, the acariform mites, the parasitiform mites, and the harvestmen.

\subsection{Morphology}

The pseudoscorpion body is divided into an anterior prosoma and a posterior opisthosoma (Fig. 2). The prosoma bears the chelicerae, which form the mouthparts; the large pedipalps, which are modified into claws; and four pairs of walking legs. The chelicerae are chelate with two articles. The fixed finger bears several thin plates, including a grooming organ: the serrula exterior. The movable finger bears a spinneret (galea) from which silk is produced. The cheliceral palm carries a grooming organ that consists of a row of thin setae: the rallum (Judson, 2007a). The pedipalps consist of a coxa, trochanter, femur, tibia, and tarsus. The tibia forms the swollen hand of the claw, which extends into the fixed finger. The tarsus forms the opposing movable finger. Both fingers of the claw bear many sensory setae that are important for species identification, as well as one or two rows of teeth on the inner surface. In some taxa one or both fingers have the openings for venom glands, although no venom glands are present in the most basal pseudoscorpion families (e.g. Chthoniidae, Feaellidae, and Pseudogarypidae). The legs usually have seven articles, reduced to six in some groups. The typical plan is a coxa, trochanter, femur, patella, tibia, metatarsus, and tarsus. Unlike most other arachnids, the femur is very short compared to the patella, which is a long article and resembles the femur of other arachnids. This caused confusion in identifying elements of the legs and led some authors to suggest that pseudoscorpions lack a patella. The prosoma is broadly attached to the opisthosoma, which is usually rounded in shape but can be compressed dorsoventrally. The opisthosoma has 12 segments, the last forming a small retractable anal cone. Most pseudoscorpions have two or four simple eyes each with a single lens, but eye reduction is frequent in the soil fauna and among cave species.

\subsection{Systematics}

The order Pseudoscorpiones currently comprises 26 Recent families (Fig. 3). Despite looking like scorpions, most phylogenetic analyses based on morphology (e.g. Shultz, 2007) suggest that pseudoscorpions are the sister group of the camel spiders (Solifugae), together forming a clade either called Apatellata - which is misleading as these animals do have a patella (see above) - or Haplocnemeta. Molecular studies sometimes yielded different results. For example, Sharma et al. (2014) recovered pseudoscorpions closest to acariform mites, but at the same time cautioned that this could be an artefact of long-branch attraction (but see Arabi et al., 2012). Overall, the position of pseudoscorpions in the arachnid tree of life is still debated and the subject of ongoing discussion.

Both Pseudoscorpiones and Chelonethi have been used as the order name for pseudoscorpions in the literature. Judson (2012) attempted to resolve this by adopting Pseudoscorpiones for the total group and Chelonethi for the crown group (i.e. all living species plus their common ancestor); but see also Sect. 4. The first comprehensive attempts to classify pseudoscorpions were made by Beier (1932a, b) and Chamberlin (1931), but it was Harvey (1992) who proposed the first objective phylogeny based on morphological characters. He distinguished two main lineages: the Epiocheirata and Iocheirata. The Epiocheirata lacks venom glands in the pedipalps and comprises two superfamilies: Chthonioidea and Feaelloidea. The presumably more derived Iocheirata possesses venom glands and includes the majority of the families. This group is further divided into Hemictenata, with a single superfamily Neobisioidea, and Panctenata with four superfamilies: Garypoidea, Olpioidea, Sternophoroidea, and Cheliferoidea. Some minor alterations to this hypothesis were subsequently proposed, and two additional families were established (Judson, 1993, 2005). The molecular phylogeny of Murienne et al. (2008) also supported Harvey's morphological results but questioned the monophyly of Neobisiodea, Garypoidea, and Cheliferoidea as they currently stand. Most importantly the Epiocheirata emerged as paraphyletic and the Feaelloidea were placed as the sister group to all other pseudoscorpions whilst Chthonioidea emerged as the sister group to a monophyletic Iocheirata.

\subsection{Fossil record}

Despite their modern diversity, fossil pseudoscorpions remain comparatively rare and almost all fossils are preserved as amber inclusions sourced from various parts of the world (Fig. 1). The oldest is Devonian in age (see below) and preserved in shales, but given their small size and relatively soft bodies, most of the fossil record is restricted to Cretaceous and Cenozoic ambers. At the time of writing, 49 valid fossil, or subfossil, species have been described in the literature (Table 1), three of which were assigned to extant 


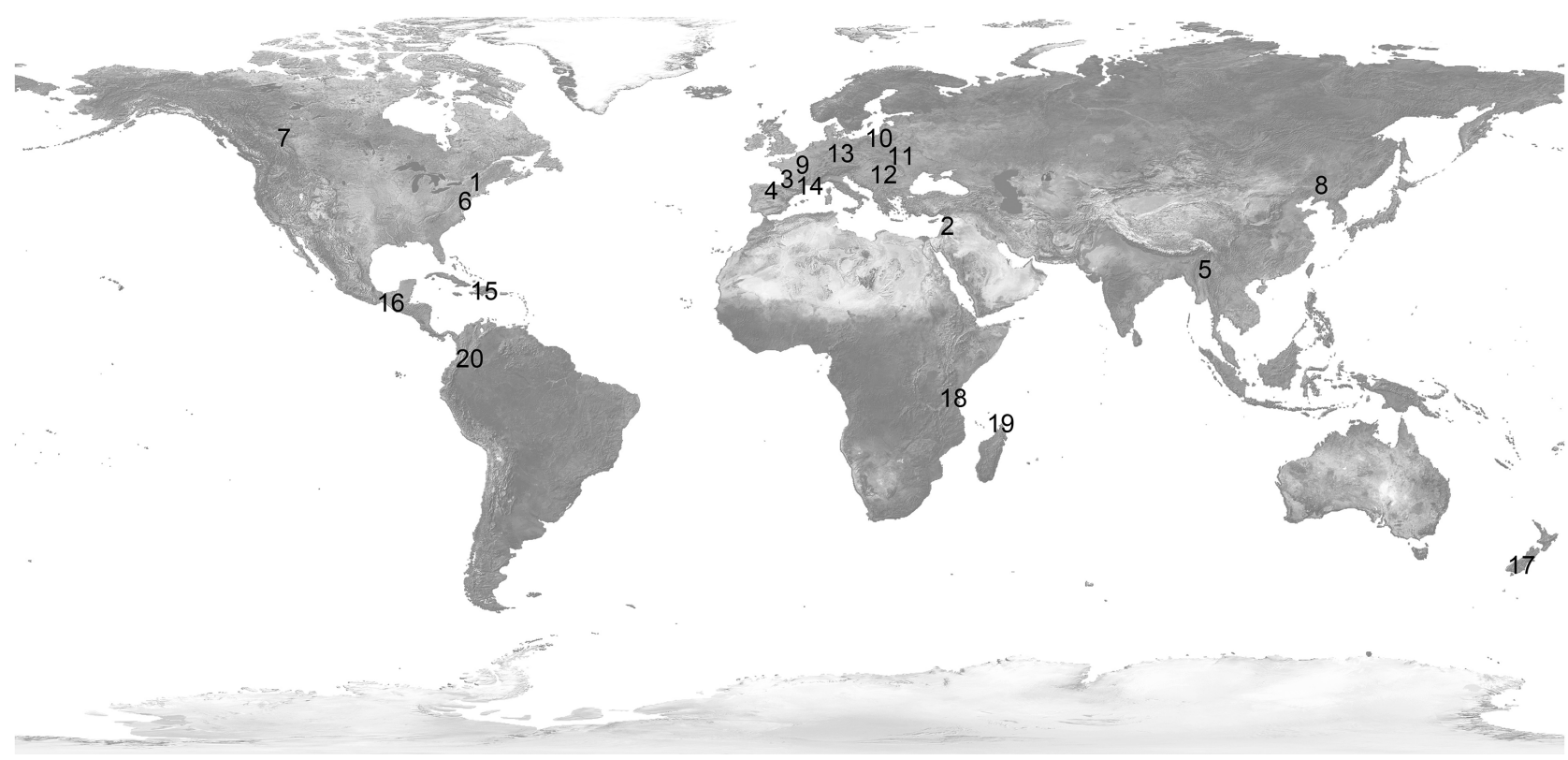

Figure 1. Global map showing the localities of the fossil deposits. 1, Gilboa; 2, Lebanese amber; 3, Archingeay amber; 4, Álava amber; 5, Burmese amber; 6, New Jersey amber; 7, Canadian amber; 8, Fushun (Chinese) amber; 9, Parisian amber; 10, Baltic amber; 11, Rovno amber; 12 Romanian amber; 13, Bitterfeld amber; 14, Aix-en-Provence; 15, Dominican amber; 16 Chiapas (Mexican) amber; 17, Kauri (New Zealand) amber; 18, East African copal; 19, Madagascan copal; 20, Colombian copal.

species. Fossil pseudoscorpions were included in the catalogues of Harvey $(1991,2013)$ and the online list of fossil arachnids by Dunlop et al. (2017). The last comprehensive review was by Petrunkevitch (1955), but his chapter in the Treatise on Invertebrate Paleontology is now very dated. The oldest records of pseudoscorpion suborders (Crowson et al., 1967) and families (Selden, 1993a) were documented in The Fossil Record and The Fossil Record 2, respectively, but again there have been several important discoveries since these publications. Amber records of pseudoscorpions, and their likely repositories, were listed by Keilbach (1982) and Spahr (1993). A checklist of fossil pseudoscorpions was also compiled by Schawaller $(1978,1980 a)$, but this is now outdated, and a partial overview of pseudoscorpion palaeontology can be found in Judson (2009) whilst there are other brief reviews by Selden (1990, 1993b), Selden and Dunlop (1998), Dunlop (1996, 2010), and Dunlop and Penney (2012), for example, as part of more comprehensive works on fossil arachnids. An online catalogue of fossil species was also compiled by Harvey (2013).

Here, we offer a modern synthesis of the pseudoscorpion fossil record and its impact on questions of evolution and historical biogeography. We document the oldest records for modern families and transpose these data onto a consensus phylogeny (Fig. 3) to give an indication of minimum ages for the major lineages currently recognised. We also review the palaeoecology of fossil pseudoscorpions, the taphonomic biases introduced by being mainly trapped in tree resin, and numerous examples of phoresy in which these animals were preserved as hitchhikers attached to insects in amber.

\section{Material and methods}

Records of fossil pseudoscorpions were primarily reviewed from the available literature, which is detailed for each of the localities below. Information on the ages of deposits was primarily sourced from the ICS International Chronostratigraphic Chart (Cohen et al., 2013). Abbreviations for museum repositories (see Table 2) are as follows: AMNH, American Museum of Natural History, New York; PCJW, private collection of Jörg Wunderlich, Straubenhardt, Germany; SMNS, Staatliches Museum für Naturkunde Stuttgart; GPIH, Geologisch-Paläontologisches Institut of the CeNak.

Amber fossils were imaged three-dimensionally using a custom-made BK Plus Lab System by Dun, Inc. and the company's software. The amber pieces were immersed in baby oil (Penaten Pflegeöl, Johnson \& Johnson $\mathrm{GmbH}$ ), which facilitates a better refractive index, and were imaged with the help of a Canon EOS 5D and a Canon MP-E $65 \mathrm{~mm}$ lens, which were integrated into the BK system. The colour plate was compiled in Adobe Photoshop CS6 and edited as necessary. The chronogram for the fossil record of pseudoscorpions was produced using Adobe Illustrator and follows Harvey (1992), but with subsequent modifications that have occurred in the classification since then (e.g. the elevation of Pseudotyrannochthoniidae and Garypinidae to family level). 


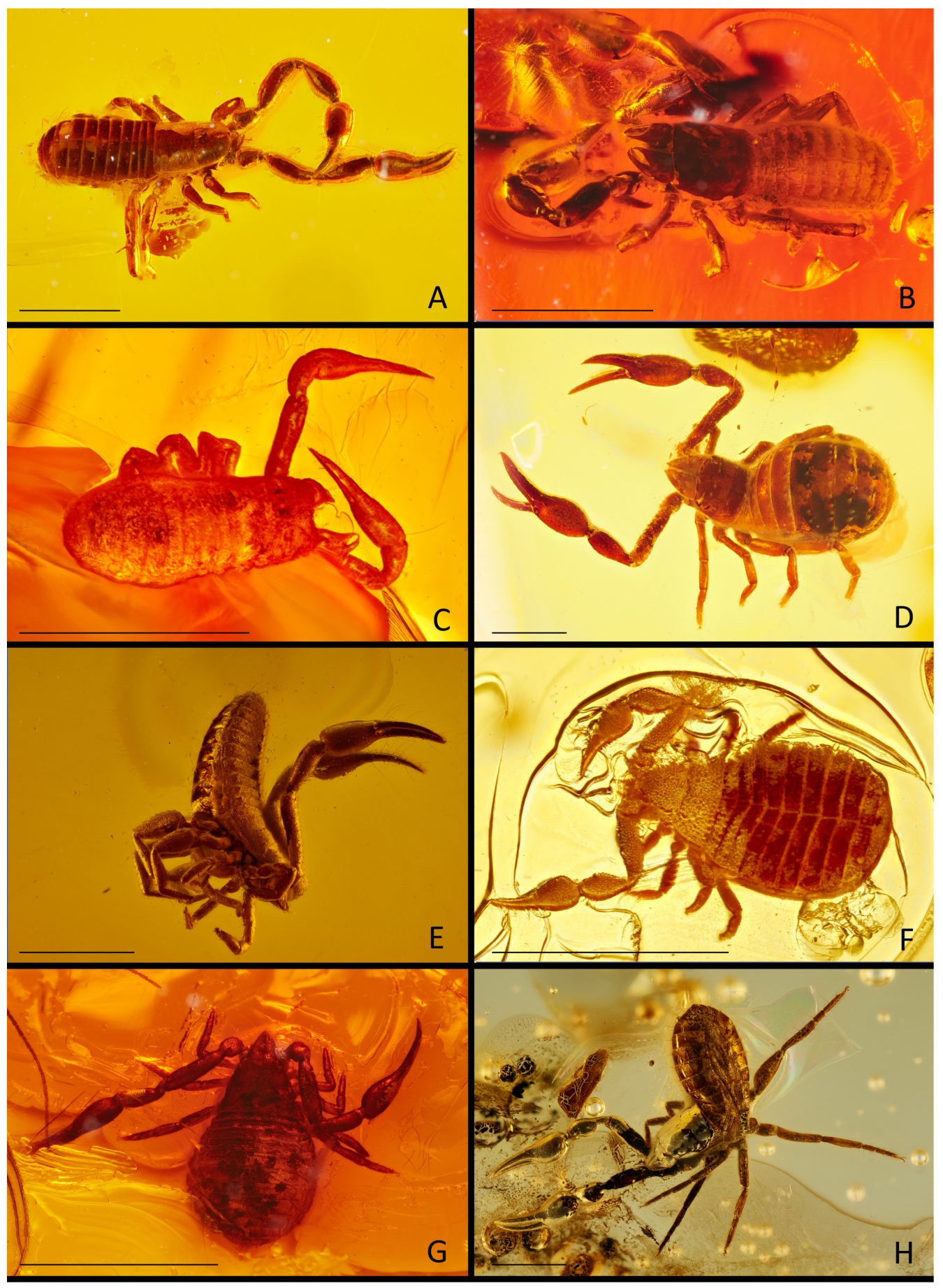

Figure 2. Example of pseudoscorpion inclusions preserved in amber. (a) Progonatemnus succineus Beier, 1955 (family Atemnidae, GPIH 266); (b) Roncus succineus Beier, 1955 (Neobisiidae, GPIH 263); (c) Chelignathus kochii Menge, 1854 (Tridenchthoniidae, GPIH 271); (d) Neobisium exstinctum (Neobisiidae, GPIH 262); (e) Electrochelifer balticus Beier, 1955 (Cheliferidae, GPIH 269); (f) Cheiridium hartmanni (Menge, 1954) (Cheiridiidae, GPIH 265); (g) Geogarypus macrodactylus Beier, 1937 (Geogarypidae, GPIH 264); (h) Microcreagris koellneri Schawaller, 1978 (Neobisiidae, SMNS BB-398-K-1). Scale bar $=1.0 \mathrm{~mm}$. 


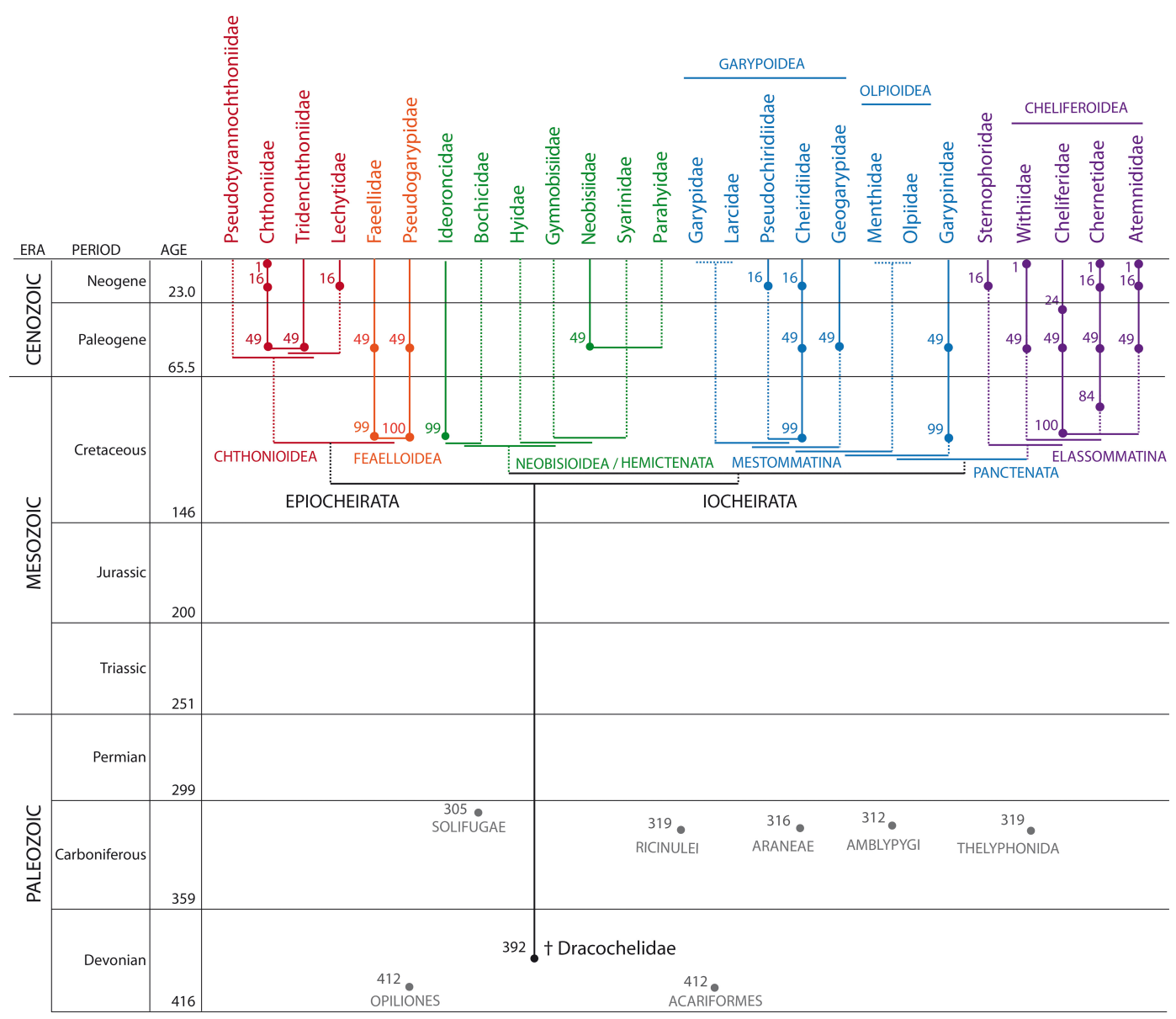

Figure 3. Evolutionary time tree for Pseudoscorpiones redrawn from Harvey (1992) with modifications according to Murienne et al. (2008). Families with a fossil record are given as solid lines and those without a fossil record as dashed lines. Minimum ages according to fossil records are indicated by a circle and the age estimates are in millions of years. Maximum age estimates for some other arachnid groups are indicated for comparison.

\section{The fossil record}

\subsection{Palaeozoic pseudoscorpions}

\subsubsection{Gilboa}

The only Palaeozoic pseudoscorpions come from the Gilboa mudstones of New York in the USA. This important terrestrial locality is dated to the Middle Devonian (Givetian, ca. $390 \mathrm{Ma}$ ). Along with fragments of early land plants, Gilboa has also yielded fossils of several other arthropod groups including centipedes, mites, and the extinct trigonotarbid arachnids. All are preserved as cuticle fragments, which were prepared by macerating both plants and animals from the matrix using hydrofluoric acid. Two pseudoscorpion specimens were first reported by Shear et al. (1989) and represented a huge extension of the group's fossil range compared to previous records from amber. Shear et al. (1989) did not assign their fossils to any modern superfamily, but were able to identify structures such as the chelicerae with flagellum, galea, and serrular exterior, which imply similarities of the Palaeozoic to the modern species, including predatory ecology, silk use, and grooming behaviour using the cheliceral serrulae. The presence of trichobothria (fine hairs that detect air currents) also provides evidence of a terrestrial lifestyle for these fossils.

A third Gilboa pseudoscorpion was subsequently discovered and the material available was formally described as Dracochela deprehendor Schawaller, Shear, and Bonamo, 1991. It was interpreted as including examples of more than one instar. The authors accommodated their species in a new, extinct family Dracochelidae, which they diagnosed as follows (Schawaller et al., 1991:3): "Resembles chthonioids and feaelloids in having a contiguous pair of bothria distal on the fixed chelal finger; differs from chthonioids in having bitarsate first legs and lacking bothria on the chelal hand, from feaelloids in the large chelicerae and smooth cuticle. Resembles neobisioids in having a cheliceral flagellum with a row of feathered setae. Differs from all three superfamilies 
in having smooth blades in the serrula interior." In comparison, Schawaller et al. (1991) felt that the characters observed were more consistent with chthonioid affinities, but refrained from placing it in this superfamily.

Dracochela deprehendor was restudied by Judson (2012), who concluded that it was better placed as a stem-group pseudoscorpion; in other words, in Judson's scheme it represents the sister group of all other pseudoscorpions. Characters that differentiate the Devonian fossils from the remaining pseudoscorpions include spinules on the leg tarsi, posterior legs in which the femur is nearly as long as the patella, and absence of a spinneret for silk production on the chelicerae. Other characters clearly align the fossil with modern pseudoscorpions, such as the unique arrangement of trichobothria on the pedipalp hand that Dracochela shares with the extant family Pseudotyrannochthoniidae but is not present in other extant pseudoscorpions. Wolfe et al. (2016) disagreed with Judson's interpretation of Drachochela as a stem-group member and referred to a morphological phylogenetic analysis that has yet to be published.

\subsubsection{Coal measures}

One of the oldest (historical) accounts of a fossil arachnid is Microlabius sternbergii Corda, 1839 from the Late Carboniferous Coal Measures of the Czech Republic. The original description by Corda (1839) referred to it as an Afterskorpion, an older German name for pseudoscorpions. The fossil in question is about $2.5 \mathrm{~cm}$ long - much larger than any living pseudoscorpion - and the pedipalps are unusually small and delicate compared to most other fossilised and living scorpions. Subsequent redescriptions (e.g. Petrunkevitch, 1953; Kjellesvig-Waering, 1986) accepted Corda's fossil as a scorpion in which the tail is not preserved. Petrunkevitch's photograph shows what look like pectines on the right side of the body, which strongly support scorpion affinities.

It should also be mentioned that Woodward (1871) and Geinitz (1882) described two arachnid fossils from the Coal Measures of England and Germany, respectively, as pseudoscorpions. With body lengths of $3-5 \mathrm{~cm}$ these specimens are again an order of magnitude larger than typical pseudoscorpions. They lack the large chelate pedipalps typical for pseudoscorpions and have since been recognised as members of the extinct arachnid order Trigonotarbida. In fairness to the original authors, the general body shape and tuberculate dorsal ornament of these Palaeozoic fossils is quite reminiscent of certain modern pseudoscorpion genera such as Cheiridium Menge, 1855, although we should reiterate that pseudoscorpions in this genus are tiny $(1.5-3.0 \mathrm{~mm})$ by comparison.

\subsection{Mesozoic pseudoscorpions}

\subsubsection{Altmühltal}

The Altmühltal Formation near Eichstätt in Bavaria, Germany, represents a lagoon environment dating to the midJurassic (Tithonian, ca. $150 \mathrm{Ma}$ ). It is famous for preserving marine animals as well as small dinosaurs and early birds such as Archaeopteryx. Although some insects, such as dragonflies, have been preserved at Altmühltal (including the famous Solnhofen Lagerstätte), unequivocal arachnid fossils are unknown. There is, however, a published name, Chelifer fossilis Weyenbergh, 1874, which would imply a pseudoscorpion. The original description by Weyenbergh (1874) is of little use in determining its affinities. Scudder (1891) suggested that the fossil was probably not an arachnid and Petrunkevitch (1953), who also photographed the holotype from the Teylers Museum in Haarlem, suggested that it could be a crustacean. The catalogue of Harvey (2013) listed it as a nomen nudum, and since the original publication only mentioned the name (without a formal indication) we concur with his opinion.

\subsubsection{Lebanese amber}

Excluding this Jurassic record mentioned above, almost all of the remaining fossil pseudoscorpions are preserved as inclusions in Cretaceous and Cenozoic ambers. It should be mentioned that there are several examples of pseudoscorpions reported in passing in more general lists of amber faunas; see also comments in Judson (2009). Thus, the second oldest pseudoscorpions come from Lebanese amber, which is dated to Upper Neocomian-basal Lower Aptian (ca. 125-135 Ma). They were noted by Whalley (1980) and Grimaldi (1996), but their affinities remain equivocal.

\subsubsection{Archingeay amber}

The oldest Mesozoic pseudoscorpions to be formally identified are two cheliferoid records, one of which was formally named, from the Archingeay amber found in the CharenteMaritime district of south-western France (Perrichot, 2004). This locality has been dated to the Cretaceous (late Albian, ca. $100 \mathrm{Ma}$ ). Heurtaultia rossiorum Judson, 2009 was placed in an extinct genus and tentatively referred to the family Cheliferidae. This referral is based on two incomplete specimens that are imperfectly preserved. Although it seems clear that Heurtaultia belongs to the superfamily Cheliferoidea, the referral to the family Cheliferidae was clearly tentative and many characters needed to ascertain this hypothesis have not been preserved. Heurtaultia rossiorum differs from extant members of the family Cheliferidae in the position of the tactile setae of the tarsi of legs III and IV, which are situated in a proximal position rather than medial or distal, which may represent the plesiomorphic condition, but again the evaluation of character states is based on limited data. A third spec- 
imen belonging to another species from Archingeay also appears to belong to the Cheliferidae, but the poor preservation of the fossil precludes any further character evaluation.

\subsubsection{Rhenish Massif}

This deposit comprises middle Cretaceous karst infillings (late Albian-early Cenomanian) in Upper Devonian limestone and the fossils are typically carbonised (Viehofen et al., 2008). A well-preserved chela belonging to a pseudogarypid pseudoscorpion has been recorded but the fossil has yet to be described (Judson, 2017). This chela represents the oldest record of the Feaelloidea and is slightly older than the records of this family from Burmese amber.

\subsection{5 Álava amber}

Of similar age is the Álava amber deposit from Spain, which also dates to the Albian (ca. 100-113 Ma). The presence of two pseudoscorpions was reported by Delclòs et al. (2007), but no further details are available. The images provided in this publication suggest that these fossils belong to the superfamily Cheliferoidea, similar to the fossils preserved in Archingeay amber, but a detailed description of these fossils is lacking.

\subsubsection{Burmese amber}

Perhaps the most productive and interesting of the Cretaceous amber sites is Burmese amber, or burmite, from Myanmar. It is one of the few localities that samples an Asian fossil fauna and is currently dated to the Cenomanian (ca. 99 Ma); see also Shi et al. (2012). Fossils from this amber were initially described in the early 20th century, including the pseudoscorpions Electrobisium acutum Cockerell, 1917 and Amblyolpium burmiticum (Cockerell, 1920). The original descriptions of both species were very brief and they remained somewhat enigmatic until Judson (2000) re-examined the types and recorded both the families Pseudogarypidae (Amblyolpium) and Cheiridiidae (Electrobisium) for the first time in Burmese amber. Both of these families are most speciose today in tropical and subtropical biomes (Harvey, 2013) and the presence of both groups in Burmese amber is therefore not surprising. Interestingly, at least one of these species can be placed without difficulties into a modern genus, suggesting that there has been very little morphological change in this group over the last 100 million years. Judson (2000) and Grimaldi et al. (2002) also referred to additional material preserved in Burmese amber comprising representatives of the superfamilies Chthonioidea, Cheiridioidea, Cheliferoidea, and Garypoidea, but these fragments are too poorly preserved for a detailed description. Many more fossils are available for sale on the internet and these include members of the families Atemnidae, Chthoniidae (probably Tyrannochthonius), Chernetidae, Feaellidae, Hyidae, and possibly Ideoroncidae. Xia et al. (2015) also illustrate what seems to be a member of the family Ideoroncidae (see also below), but this book does not include a formal taxonomic description.

Most recently, Protofeaella peetersae Henderickx in Henderickx \& Boone, 2016 was described from Burmese amber, although material probably belonging to this species was previously illustrated by Xia et al. (2015). Feaellidae are the most basal pseudoscorpion lineage according to Murienne et al. (2008) and extant species of the genus Feaella and the related genus Iporangella occur in disjunct distributions in tropical and subtropical biomes, such as tropical Brazil (Harvey et al., 2016), Africa/Madagascar, India/Sri Lanka, and Australia (Harvey, 2013). This implies a former Gondwanan or even Pangaean distribution of this group. Very recently, a new subfamily Cybellinae has also been described from South East Asia for two species of the newly formed genus Cybella from caves in Cambodia and Vietnam (Judson, 2017). The amber genus Protofeaella differs from extant members of the family by some morphological characters such as an elongate carapace and relatively long chelal fingers that lack a tuberculate basal tooth (Henderickx and Boone, 2016; Judson, 2017). Nevertheless, it shares with $C y$ bella the plesiomorphic absence of pleural plates and the antiaxial position of the chemosensory setae of the movable chelal fingers. Protofeaella peetersae is currently considered a stem-group feaellid by Judson (2017), and we agree with this conclusion. Overall, it is clear that a diverse pseudoscorpion fauna, both at the family and species level, is preserved in Burmese amber and that many more interesting taxa remain to be described from this diverse deposit. Most fossils can easily be assigned to Recent genera despite the age of these fossils.

\subsubsection{New Jersey amber}

This deposit, sometimes referred to as Raritan amber, from the eastern USA is dated to the Turonian stage of the Cretaceous (ca. 90-94 Ma). Records of pseudoscorpions from New Jersey amber were mentioned by Grimaldi et al. (2002), but no further details are available and no detailed descriptions have been published.

\subsubsection{Canadian amber}

The final Mesozoic record is a single (unnamed) pseudoscorpion from Canadian amber. This material comes from Grassy Lake in southern Alberta, Canada, and is dated to the Campanian (ca. 72-84 Ma). The fossil in question is a deutonymph and very little can be said other than that it belongs to the cosmopolitan family Chernetidae (Schawaller, 1991).

\subsection{Cenozoic pseudoscorpions}

\subsubsection{Fushun amber}

The Fushun amber found in Liaoning Province of China, sometimes referred to more generally as Chinese amber, is 
interpreted as being of lower Eocene age (early-middle Ypresian, ca. 50-53 Ma); see Wang et al. (2014) for an overview of the geological setting and the fauna. A diverse arthropod biota is known from this deposit and a single pseudoscorpion species in a new, extinct genus was described as Trachychelifer liaoningense Hong, 1983 in the family Cheliferidae. In the description, the species is compared with the Baltic fossil genus Oligochelifer but no comparison is made with the Recent chernetid fauna in China, which is probably diverse but poorly known. In fact, the drawings as presented are too stenographic to compare the fossil with Recent genera in this region such as Haplochernes (Gao et al., 2017) and the generic classification of Trachychelifer should be considered as tentative.

\subsubsection{Oise (Le Quesnoy) amber}

This French amber deposit also dates to the lower Eocene (Ypresian, ca. $53 \mathrm{Ma}$ ) and includes a pseudoscorpion mentioned by Nel et al. (1999), which Judson (2009:62) subsequently identified as belonging to the family Garypinidae. This family is also known from the Burmese and Baltic ambers, but Judson refrained from describing the species. No additional data are currently available.

\subsubsection{Baltic amber}

Baltic amber is the primary source of data on fossil pseudoscorpions, having been extensively sampled for more than 150 years. It currently yields 34 valid species in 12 families, which represents almost two-thirds of all pseudoscorpion fossils described so far. Baltic amber - sometimes referred to as Prussian amber in the older literature - can be found all around the entire coast of the Baltic Sea. Many inclusions offered for sale in recent years stem from the Kaliningrad region of the Baltic coast of Russia, but it is rare to be able to tie an individual piece to a specific collecting site and it is usual to refer to all this material as coming from a more general Baltic amber forest that was potentially widespread in Europe. A range of published ages can be found in the literature, with most modern authors tending towards an Eocene (Lutetian) age of about 44-49 Ma.

Historically, the oldest Baltic amber pseudoscorpion species were those described by Koch and Berendt (1854). Their two valid species have been transferred to other genera (Beier, 1937; Judson, 2003) since the original description and currently consist of Pseudogarypus hemprichii (Koch and Berendt, 1854) in the family Pseudogarypidae and Pycnochelifer kleemanni (Koch and Berendt, 1854) and its synonym Obisium rathkii Koch and Berendt, 1854 in the family Cheliferidae. There is as also the published name Chelifer ehrenbergii Koch and Berendt, 1854, which is currently considered a nomen dubium (Harvey 2011). Koch and Berendt's monograph was compiled posthumously by Anton Menge, who added five species of his own in footnotes to this work. These comprise Chelignathus kochii Menge, 1854, described in an extinct genus in the family Tridenchthoniidae; Cheiridium hartmanni (Menge, 1854) in Cheiridiidae; Dichela berendtii Menge, 1954, an extinct genus of Cheliferidae; Oligochernes wigandi (Menge, 1854) in Chernetidae; and Beierowithius sieboldtii (Menge, 1854) in Withiidae. A general problem with Menge's descriptions is (a) that they were often extremely brief, (b) lacked illustrations, and (c) the type material that is thought to have been in Gdańsk, Poland, is believed to be lost (Dashdamirov, 2008). This raises difficulties in testing the validity of his names. However, Beier (1937) redescribed some of the species based on the original specimens before they were lost, and we rely on his interpretations.

Most Baltic amber inclusions were described by Max Beier, one of the most experienced researchers of living pseudoscorpions. He also made the largest single contribution to the fossil fauna, describing 17 species in three papers (Beier, 1937, 1947, 1955). Chthonius (Chthonius) mengei Beier, 1937 was placed in the family Chthoniidae; Pseudogarypus extensus Beier, 1937 and P. minor Beier, 1947 in Pseudogarypidae; Neobisium (Neobisium) exstinctum Beier, 1955 and Roncus succineus Beier, 1955 in Neobisiidae; Garypinus electri Beier, 1937 in Garypinidae; Geogarypus macrodactylus Beier, 1937 and G. major Beier, 1937 in Geogarpyidae; and Progonatemnus succineus Beier, 1955 in Atemnidae. Several species of Cheliferidae were described in two extinct genera, namely Dichela gracilis (Beier, 1937); D. granulatus (Beier, 1937); D. serratidentatus (Beier, 1937); Electrochelifer bachofeni Beier, 1947; E. balticus Beier, 1955; E. mengei Beier, 1937; and E. rapulitarsatus Beier, 1947. Finally, he described Oligochernes bachofeni Beier, 1937 in the family Chernetidae. Again, the works of Beier are not unproblematic because he tended to establish genera for fossil species that were not properly diagnosed and often provided conflicting evidence in his descriptions; see also comments in Dashdamirov (2008). Again, the restudy of material is complicated because the types may be lost (misplaced or destroyed during World War II) and we often have to rely on the original descriptions.

Later work on the Baltic amber fauna included three species added by Schawaller (1978) and Judson (2003): the chthoniid Chthonius (Chthonius) pristinus Schawaller, 1978 and the neobisiids Microcreagris koellnerorum Schawaller, 1978 and Neobisium henderickxi Judson, 2003. The most recent descriptions include the geogarypid Geogarypus gorskii Henderickx, 2005 and the pseudogarypids Pseudogarypus pangaea Henderickx et al., 2006 and $P$. synchrotron Henderickx et al., 2016, including some records that are notable for having been studied and reconstructed as virtual fossils using computed tomography techniques. Indeed the 2006 paper was one of the first to successfully apply these techniques to arachnid inclusions in amber. Judson (2003) also described Garypinus electri Judson, 2003 in the family Garypinidae using conventional methods. Of major interest was the re- 


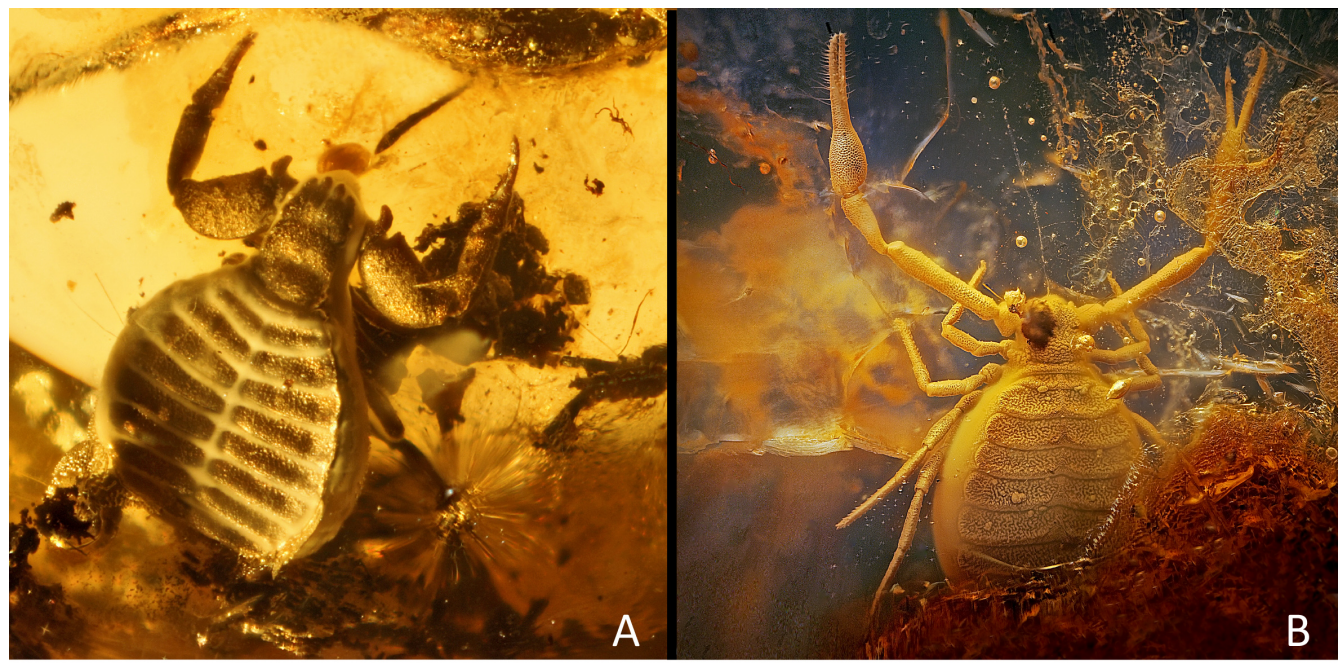

Figure 4. Fealla groehni (a) and Pseudogarypus synchotron (b) specimens from Baltic amber. The families Pseudogarypidae and Feaellidae are closely related and constitute the superfamily Fealloidea. Feaellidae today is present in Mediterranean and tropical climates and Pseudogarypidae is restricted to temperate climates. Both families exclude each other in distribution today but are present in Baltic amber.

cent description of Feaella (Tetrafeaella) groehni Henderickx in Henderickx and Boone, 2014 belonging to the family Faellidae (Fig. 4). As noted above for Burmese amber, this family is known today only from Mediterranean and tropical biomes on former Gondwanan landmasses. Thus, the fossil represents the first record of this family from former Laurasia and suggests that this group may be considerably older, most likely with origins on Pangaea before its break-up. Overall, Baltic amber remains the main source for fossil pseudoscorpions, but considerable problems exist with accessibility and hence interpretation of these fossils, particularly those described in the 19th century.

\subsubsection{Rovno (Rivne) amber}

The Rovno (Rivne) amber from Ukraine (Klesov and Volnoje) is generally accepted as having been more or less contemporary with Baltic amber, albeit perhaps from a geographically independent deposit. Several insects and arachnids are common to both ambers; see e.g. Perkovsky et al. (2007). To date, the pseudoscorpion fauna has not been examined in detail but two species have been formally recorded. Geogarypus gorskii was reported by Henderickx and Perkovsky (2012). Pseudogarypus minor was reported by Henderickx et al. (2013) and again studied with the aid of computed tomography. Both species are also known from Baltic amber (see above) and would support the idea that the two ambers are of a similar Eocene age and reflect a common palaeoenvironment.

\subsubsection{Romanian amber}

Rumanite (Romanian amber) has long been considered to be a separate fossil resin from Baltic amber but may in fact share the same origin although being thermally degraded (Stout et al., 2000). Pseudoscorpions were briefly mentioned as being present by Protescu (1937), but no additional data are available.

\subsubsection{Bitterfeld amber}

Bitterfeld amber comes from Bitterfeld in the state of Saxony-Anhalt in the eastern part of Germany (Gröhn, 2010). It is thus sometimes referred to as Saxon, or Saxonian, amber. There has been much discussion in the literature about whether Bitterfeld amber is simply a more southerly extension of the Baltic amber forest, or whether it is an independent and potentially younger (perhaps Oligocene, ca. $24 \mathrm{Ma}$ ) deposit; see e.g. Bartel (2015, and references therein) for a discussion. In brief, the palaeontological evidence tends to support the idea that the two ambers are equivalent in that several species of insects and arachnids are common to both sources. By contrast, evidence from the geological setting and geochemistry (Wolfe et al., 2016) tends to support the distinctness of the Bitterfeld deposit, whereby it should be cautioned that older amber could potentially have been reworked into younger sediments. Resolving this issue is important because if these ambers are of different ages and yet contain identical species it implies a long period of faunal stability during the Eocene-Oligocene of north-central Europe, with morphospecies that may have remained unchanged for more than 20 million years. 
Schumann and Wendt (1989) offered an initial list of the animals found in Bitterfeld amber. The arachnids - identified by the then curator in Berlin, Manfred Moritz - included material provisionally assignable to the family Cheliferidae. We are aware of further Bitterfeld pseudoscorpions that await study in, for example, the Hamburg museum. These could allow us to test whether there are species shared between Baltic and Bitterfeld amber or whether Bitterfeld amber had its own endemic taxa.

\subsubsection{Aix-en-Provence}

The locality of Aix-en-Provence in south-eastern France represents a large, shallow lacustrine environment dated to the late Oligocene (ca. 22.5 Ma); see also Nury (1990) for details. It has yielded a diverse fauna of both vertebrates and invertebrates, including several well-preserved fossils of insects and arachnids. Hope (1847) mentioned a Chelifer from this locality, which would potentially be one of the very few non-amber records. Judson (2009) cautioned that at that time this was a fairly general name for pseudoscorpions and it would be unwise to draw conclusions about familial affinities. He also mentioned that the material on which Hope's observations were based could not be traced, rendering this record a nomen dubium.

\subsubsection{Dominican amber}

The Neotropical fossil pseudoscorpion fauna is sampled by amber from both the Dominican Republic and the state of Chiapas in Mexico. Amber from the Dominican Republic on the island of Hispaniola has been sampled since the 1970s. As with many ambers, the age of the deposit has proved controversial but is now usually given as Miocene (Burdigalian, ca. $16 \mathrm{Ma}$; Penney, 2008). Six species of pseudoscorpion have been formally described from Dominican amber. The first to be named was Pachychernes effossus Schawaller, 1980a from the family Chernetidae and additional chernetid fossils of this genus are known but not named. It was followed by Pseudochthonius squamosus Schawaller, 1980b (Chthoniidae) and Lechytia tertiaria Schawaller, 1980b. The latter is the first, and so far only, fossil record of the family Lechytiidae. Cryptocheiridium (Cryptocheiridium) antiquum Schawaller, 1981a belongs to the family Cheiridiidae. A particularly interesting record was described by Judson (1998) and assigned to the extant Neotropical species Idiogaryops pumilus (Hoff, 1963). It is the only fossil example of the family Sternophoridae and one of the few examples of a living species found in an amber deposit that is not young enough to be considered a subfossil (see below). The final species is Pseudochiridium lindae Judson, 2007b, again the first and only record of its respective family Pseudochiridiidae. Additional fossil pseudoscorpions have been illustrated or mentioned in the literature but not formally described (e.g. Penney, 2008).

\subsubsection{Chiapas amber}

Contemporary with Dominican amber is the Miocene Chiapas amber of Mexico, sometimes referred to more generally as Mexican amber. Pseudoscorpions were first described from this deposit by Schawaller (1982), who recorded a protonymph and was able to assign it to the family Chernetidae. The first one to be formally named was Byrsochernes maatiatus (Riquelme, Piedra-Jiménez, and Córdova-Tabares in Riquelme et al., 2014), also from the family Chernetidae. This species was initially assigned to a new, extinct genus, Mayachernes Riquelme, Piedra-Jiménez \& CórdovaTabares, 2014. It was transferred to an existing Recent genus from the Neotropics by Judson (2016) because of similarities in trichobothriotaxy and chaetotaxy (e.g. position of the trichobothria and tactile setae on leg IV). In the same paper a second species was described as Paraliochthonius miomaya Judson, 2016 from the family Chthoniidae, together with several other provisional records documenting a range of families, including a Tyrannchthonius sp. (Chthoniidae), Paratemnoides (?) sp. (Atemnidae), Lustrochernes (?) sp. 1-2 (Chernetidae), and Cheliferini gen. sp. indet; see Judson (2016) for further details.

\subsubsection{New Zealand amber}

A final source of fossil material is New Zealand Kauri amber, which has only received recent scientific attention. Schmidt et al. (2014) briefly described a community of fossil arthropods preserved in amber ranging in age from the Cretaceous to Miocene, comprising a variety of mites and spiders but also a pseudoscorpion. No additional data are currently available.

\subsection{Subfossils}

\subsubsection{East African copal}

Copal is a subfossil resin that would eventually further harden to form amber. Historically, the oldest available name for an extinct pseudoscorpion is Chelifer eucarpus Dalman, 1826. This specimen probably comes from East African copal, possibly from Zanzibar in Tanzania; see Judson (2010) for a justification of its likely provenance. Like amber, copal deposits are difficult to age accurately and may be only a few hundred years old. A Pliocene age of up to $1.8 \mathrm{Ma}$ has been proposed for the East African material (e.g. Schlüter, 1993), but a precise date remains equivocal. Judson (2010) redescribed the holotype from Dalman (1826) from the Naturhistoriska Riksmuseet in Stockholm, clarified its date of publication, which had sometimes been cited as 1825 , identified it as a tritonymph, and transferred it to the genus Withius Kew, 1911 as Withius eucarpus (Dalman, 1826). Possible affinities with the extant species Withius glabratus (Ellingsen, 1910) were also discussed. 


\subsubsection{Madagascan copal}

Further subfossils, all from the Jörg Wunderlich private collection, were described from Madagascan copal by Judson (2010). At the same time, he noted that the young age of the fossil resins means that any species encountered here are likely to still be present in this region today. For this reason, Judson (2010) cautioned against officially naming new species based on such subfossil material. In this context, Madagascan copal has yielded a Tyrannochthonius sp. (Chthoniidae) and a deutonymph exuvium in the family Atemnidae. Judson (2010) commented that the almost cosmopolitan genus Tyrannochthonius is known from Madagascar today, but that no living species to which the copal specimen could be compared have been formally described.

\subsubsection{Colombian copal}

Judson (2010) described two subfossil pseudoscorpions from Colombian copal derived from Hymenaea resin, again derived from the Wunderlich collection. Paratemnoides nidificator (Balzan, 1888) from the family Atemnidae is an extant species with a wide distribution in the Neotropics, including Colombia. The second specimen was tentatively assigned to another extant species, Pachychernes aff. subrobustus (Balzan, 1892) from the family Chernetidae. The copal specimen differed from modern examples of the species in some fine details of body size and the number of antiaxial accessory teeth on the chelal fingers. It is the first record of the genus for Colombia.

\section{Discussion}

Pseudoscorpions are clearly an ancient group and probably belong to the earliest arthropods to have colonised the land. Drachochela deprehedor puts the origins of Pseudoscorpiones back into the Middle Devonian and only a few arachnids have an older fossil record (Dunlop, 2010). Scorpions are known from the mid-Silurian; the extinct trigonotarbids from the late Silurian; and harvestmen, acariform mites, and the extinct phalangiotarbids from the Early Devonian (Fig. 3). By comparison, both centipedes and millipedes are older and known from the Silurian - although at least the millipedes may actually be Devonian (Suarez et al., 2017) - and some of the oldest hexapods (collembolans and probable insects) are from the Early Devonian. Most of the other arachnid groups have a fossil record that is somewhat younger (Dunlop, 2010; Dunlop and Penney, 2012), with groups such as Solifugae (camel spiders), Ricinulei (ricinuleids), Araneae (spiders), Amblypygi (whip spiders), and Uropygi (whip scorpions) first recorded unequivocally from the Late Carboniferous and potentially originating later. Winged insects radiated only much later during the Carboniferous.

The pseudoscorpion fossil record differs somewhat from that of (physically) larger and diverse clades of arachnids like scorpions, harvestmen, or spiders. Here there are several records from the Palaeozoic, and at least in scorpions there is a clear sequence of fossils that appear to document the shift from the stem-group forms through to modern crowngroup forms during the Carboniferous (e.g. Jeram, 1994a, b). In spiders (reviewed by Selden and Penney, 2010) there is also a morphological progression from the most basal clade (mesotheles) in the Carboniferous to the first araneomorphs and mygalomorphs in the Triassic and then increasing numbers of modern families from the Jurassic onwards. Pseudoscorpions are, by contrast, small animals typical of cryptic habitats (litter, bark, caves) and their fossil record is strongly biased towards amber. In this context, their fossil record shares some similarities with several clades of acariform mites (Dunlop and Penney, 2012). These mites may be known from (rare) Palaeozoic examples, but only begin to be documented with any frequency from the Cretaceous and can often be placed in living families and genera. The amber faunas of pseudoscorpions then become more like those of other arachnids in that they document a mixture of living and extinct genera, some of which reveal interesting patterns of biogeography as discussed below. Nevertheless, one may speculate that pseudoscorpions originated earlier than some other arachnid groups such as the spiders, and based on the Devonian fossils may have diversified into major clades earlier.

\subsection{The oldest pseudoscorpion}

The description (Schawaller et al., 1991), and subsequent reanalysis (Judson, 2012), of Dracochela deprehendor highlights an interesting case of morphological stasis over almost 390 million years. The Devonian species shares many synapomorphies, such as the pedipalp with two chelal fingers, the chelicera with serrulae, the tarsi of the legs with aroliae, and the presence of three nymphal stages, with modern pseudoscorpions. In fact, the similarities in some character states between this fossil and certain extant groups are striking. We could highlight the unique arrangement of the trichobothriotaxy such as the close proximity of trichobothria $i s b$ and $i b$ in a distal position on the chelal hand, which Dracochela shares with the extant family Pseudotyrannochthoniidae but not other pseudoscorpions. Overall, the oldest fossil example is clearly recognisable as a pseudoscorpion although it does differ from all Recent forms in a suite of morphological characters, most notably the lack of a spinneret, and thus implicitly the inability to produce silk, and the presence of numerous spinules on the leg tarsi. Both these character states in the fossil are probably plesiomorphic (Judson, 2012).

We follow Judson's interpretation of Dracochela as a stem-group pseudoscorpion, preserving a unique set of plesiomorphic and derived character states. Dracochela also reveals the important traits of the order such as a terrestrial lifestyle - clearly indicated by the presence of trichobothria 
on the chelal fingers and a cuticle structure that suggests life under humid conditions such as leaf litter. It presumably had a carnivorous ecology, probably with external digestion of prey, and thanks to the aroliae on the tips of the legs, it had the ability to climb smooth surfaces. The implication is that both morphology and biology have changed little over time and Dracochela may have lived in the leaf litter of lycopsid plants (Schawaller et al., 1991).

Leaf litter and the upper soil layers are still the most important habitats of pseudoscorpions today; thus, these animals are strong candidates for being an excellent example of niche conservatism and evolutionary stasis. The harvestman suborder Cyphophthalmi shares a similar biology with most pseudoscorpions in that these animals live exclusively in moist leaf litter and are carnivorous. The fossil record is sparse but dated molecular phylogenies suggest that Cyphophthalmi arose over 400 million years ago, with a subsequent diversification on the ancient supercontinent Pangaea some 70 million years later (Clouse et al., 2016). Their morphology has probably changed little since then and both groups may be examples in which diversification is primarily driven by vicariance, with ecological niche differences accumulating much later (Peterson et al., 1999).

\section{Stem and crown groups}

As noted above, Dracochela deprehendor is best interpreted as a stem-group species that lacks some synapomorphies that characterise the crown (contra Wolfe et al., 2016). It dates the total-group pseudoscorpions to ca. $390 \mathrm{Ma}$ (Table 2). If the Haplocnemata phylogenetic hypothesis (i.e. Pseudoscorpiones + Solifugae) is correct, $D$. deprehendor offers a minimum age for the split between pseudoscorpions and camel spiders because the oldest fossils of Solifugae are much younger and date to the Late Carboniferous (ca. 305 mya; Dunlop, 2010). Were pseudoscorpions to prove to be closer to, say, Acariformes, the split would be somewhat older; constrained by the presence of these mites in the Early Devonian (ca. $412 \mathrm{Ma}$ ) Rhynie chert of Scotland (Hirst, 1923).

The stem- and crown-group interpretation relates to a further issue of nomenclature in that two alternative ordinal names have been widely used for pseudoscorpions: Pseudoscorpiones de Geer, 1778 and Chelonethi Thorell, 1883. A third name, Chernetes Simon, 1879, exists but is little used. Higher taxa are not governed by the International Code of Zoological Nomenclature leaving the choice of name largely to the personal preference of individual authors. Formal attempts have been made to stabilise the classification on Pseudoscorpiones (e.g. Savory, 1972) and most modern authors have tended to adopt this name. Judson (2012) attempted to reconcile the problem by proposing Pseudoscorpiones as the name for the total-group and Chelonethi for the crown-group. We refrain from adopting this terminology because it is rather confusing and there appears to be little reason for introducing two terms for a single evolutionary unit (that is the stem plus crown group). We propose the much simpler (and elegant) solution of retaining the single name Pseudoscorpiones for the total group over time.

\subsection{Systematics}

\subsubsection{The knowledge gap}

A striking aspect of the pseudoscorpion fossil record remains the huge gap of about 260 million years between the oldest (Devonian) record and the next fossils found in the Cretaceous Lebanese amber (Fig. 3). None of the intervening arachnid-bearing localities have yielded fossil pseudoscorpions - a handful of misidentifications from the Carboniferous Coal Measures notwithstanding - and as noted above the chance of finding them in non-amber deposits is rather unlikely. The best hope for finding further Palaeozoic or early Mesozoic pseudoscorpions may be acid-maceration of sediments, which occasionally yield elements of the soil fauna such as oribatid mites (e.g. Braun, 1997; Subías and Arillo, 2002).

Fossils can be of considerable value as calibration points for estimating times of cladogenesis in molecular phylogenies. The Devonian records indicate the antiquity of totalgroup pseudoscorpions. However, their reinterpretation as a stem species - plus the lack of a further Palaeozoic record and the fact that the oldest crown-group pseudoscorpions are Cretaceous or younger - introduces difficulties for using the fossils in such analyses. In other words, the divergence times of the major lineages are likely to have been very old, but the known fossils are probably much too young to offer meaningful calibrations for recovering deep splits in the phylogeny. For discussion of a similar situation involving armoured harvestmen (Laniatores) see Dunlop (2007) and Selden et al. (2016): Laniatores are also first recorded from the Cretaceous, but presumably originated much earlier during the Devonian or Silurian. Like pseudoscorpions, they have considerable ghost ranges of and a fossil record which is too fragmentary to tell us much about their origins and evolution. Despite these limitations, the pseudoscorpion fossil record remains useful for delimiting a minimum age for families (Fig. 2; Table 2) and genera and, by implication, their respective sister-groups if these taxa lack a fossil record themselves. The problems of calibrating molecular phylogenies in such old groups are well-known and several studies have relied instead on secondary calibrations to date them (e.g. the appearance of the first forests in the Devonian for onychophorans; Murienne et al., 2013) or mixed sets of morphology and DNA sequence data with the inclusion of stemgroup fossils (e.g. archaeid spiders, see Wood et al., 2012). 


\subsubsection{Amber records}

The next fossil pseudoscorpions (Table 1) come from Cretaceous deposits, principally Archingeay and Burmese amber. Where they have been formally identified, these amber fossils can invariably be attributed to several modern families and even modern genera. This suggests that the radiation of the crown group occurred much earlier, perhaps even in the Palaeozoic, which is in contrast to other arachnid groups such as spiders. In detail, Burmese amber is almost 100 million years old but hosts fossils belonging to at least four extant superfamilies (Judson, 2009) (see also Table 2). Several Recent genera are present that belong to both relatively basal groups (e.g. Chthonioidea) and those that are more derived in all available phylogenies, potentially having evolved later (e.g. Garypoidea). Genera that are extinct (e.g. Protofeaella and Heurtaultia) are not necessarily stem-group members with primarily plesiomorphic characters either because they were described from incompletely preserved fossils or from those that carry all the family characteristics in which the genera are placed. Overall, the amber data suggest that a fully diversified pseudoscorpion fauna was established by the Cretaceous with local faunas that, in many cases, can still be found in the same areas today. This leaves us with a gap in the fossil data between the Devonian and Cretaceous in which diversification must have occurred, but the exact timing of such events and diversification patterns remains elusive. The general pattern of morphological stasis is carried over into the Cenozoic records. A number of extinct genera have been described from Baltic amber (see below). More recent faunas, such as those described from Mexican and Dominican amber, essentially describe a pseudoscorpion fauna similar to those found in these geographical areas today. Little evolutionary signal can be deduced from these samples other than that they represent a first record for a particular family or assist in characterising the palaeofauna of particular regions.

\subsubsection{Extinct genera}

As a stem-group pseudoscorpion, Dracochela differs from living species and obviously merits both an extinct genus and family. Several extinct genera have also been proposed for the amber fauna. Compared to other arachnids (e.g. spiders and harvestmen) a mixture of extinct and extant genera is not unusual among amber faunal assemblages. In detail (Table 1), about a third of the amber pseudoscorpion genera (12 from 33) are extinct taxa and slightly more than a third of the species (18 from 49) are currently assigned to an extinct genus. Intuitively, we would expect extinct genera to be more common among older records. This is borne out by the current dataset in which extinct groups are found in the Cretaceous Burmese and Archingeay ambers and in the Eocene Baltic and Chinese ambers, but not in the Miocene Dominican or Mexican ambers or in copal, which is substantially younger.
Several extinct genera were proposed a long time ago (Menge, 1854; Cockerell, 1917; Beier, 1937, 1955), and while these authors were undoubtedly experienced arachnologists it is worth revisiting their historical diagnoses, which are outdated from a modern perspective and appear to be largely based on phenetics (but see Dashdamirov, 2008). It is interesting to note that no additional extinct genera have been described from Baltic amber since the advent of phylogenetic systematics. A detailed redescription of all the historical material in Baltic amber may be impossible because some collections have been lost (Menge's), or are in poor condition with darkened and oxidised amber (Koch \& Berendt). Notable difficulties exist in the Baltic amber fauna belonging to the superfamily Cheliferoidea (i.e. the families Atemnidae, Cheliferidae, and Chernetidae) in which even the classification of modern faunas is problematic and no phylogenetic framework exists within which to evaluate character states and homologies in fossils. For example, Dashdamirov (2008:11) noted that the systematics of fossil Cheliferidae "can very generously be termed as misleading and unreliable" and that fossil genera such as Electrochelifer "seem to be an artificial assemblage". Unfortunately, the revision of this historical material is only useful to a certain extent in the absence of a proper systematic framework for the modern fauna. It is beyond the scope of the present study to provide a detailed account of these extinct genera and it may be best to consider the Baltic amber fauna of at least the cheliferoid pseudoscorpions to be very diverse, but not properly classified.

Other extinct taxa include the Burmese amber species Protofeaella peetersae, which is clearly different from extant genera of Feaellidae, and the cheiridioid Electrobisium acutum, which may in fact belong to the Recent genus Cryptocheiridium. This genus has several described species from Taiwan, the Philippines, and Malaysia (Harvey, 2013), but Electrobisium was not synonymised with Cryptocheiridium by Judson (2000) because the modern taxon may not be monophyletic. The fossil genus Heurtaultia from French Cretaceous amber is based on incomplete and imperfectly preserved fossils and little can be said about them other than that they belong to the superfamily Cheliferoidea (Judson, 2009). Similar problems arise for the fossil genus Trachychelifer from Hong (1983) with a single species from Chinese amber. The modern cheliferid fauna of China is virtually unknown, making it difficult to compare the specimen with living representatives in this area.

\subsubsection{Cryptic morphology}

An additional problem with interpreting pseudoscorpions in amber is cryptic and conservative morphology, which can be observed both between species and sometimes even between genera. Recent molecular studies have documented clouds of genetic diversity and potentially many cryptic pseudoscorpion species in groups such as the chthoniids (e.g. Harrison et 
Table 1. Summary of the 49 valid species of fossil pseudoscorpion in the literature, plus additional records from oldest to youngest.

\begin{tabular}{|c|c|c|}
\hline & Family & Reference(s) \\
\hline \multicolumn{3}{|l|}{ Palaeozoic record } \\
\hline \multicolumn{3}{|l|}{ Gilboa, USA (ca. 390 Ma) } \\
\hline 1. ${ }^{\mathrm{a}}$ Dracochela deprehendor & ${ }^{\mathrm{a} D}$ Dracochelidae & Shear et al. (1989); Schawaller et al. (1991); Judson (2012) \\
\hline \multicolumn{3}{|l|}{ Mesozoic records } \\
\hline \multicolumn{3}{|l|}{ Lebanese amber (ca. 125-135 Ma) } \\
\hline Unidentified species & $?$ & Whalley (1980); Grimaldi (1996) \\
\hline \multicolumn{3}{|l|}{ Archingeay amber (ca. $100 \mathrm{Ma}$ ) } \\
\hline 2. ${ }^{\mathrm{a}}$ Heurtaultia rossiorum & Cheliferidae? & Judson (2009) \\
\hline Unidentified species & Cheliferidae? & Judson (2009) \\
\hline \multicolumn{3}{|l|}{ Álava amber (ca. $100 \mathrm{Ma}$ ) } \\
\hline Unidentified species & $?$ & Delclòs et al. (2007) \\
\hline \multicolumn{3}{|l|}{ Burmese amber (ca. $99 \mathrm{Ma}$ ) } \\
\hline 3. ${ }^{\mathrm{a}}$ Protofeaella peetersae & Feaellidae & Henderickx and Boone (2016) \\
\hline 4. ${ }^{\mathrm{a}}$ Electrobisium acutum & Cheiridiidae & Cockerell (1917) \\
\hline 5. Amblyolpium burmiticum & Garypinidae & Cockerell (1920) \\
\hline Cheliferoidea indet. & Cheliferidae & Judson $(2000,2009)$ \\
\hline \multicolumn{3}{|l|}{ New Jersey amber (ca. 90-94 Ma) } \\
\hline Unidentified species & $?$ & Grimaldi et al. (2002) \\
\hline \multicolumn{3}{|l|}{ Canadian amber (ca. 72-84 Ma) } \\
\hline Unidentified species & Chernetidae & Schawaller (1991) \\
\hline \multicolumn{3}{|l|}{ Cenozoic records } \\
\hline \multicolumn{3}{|l|}{ Fushun amber (ca. 50-53 Ma) } \\
\hline 6. ${ }^{\mathrm{a}}$ Trachychelifer liaoningense & Cheliferidae & Hong (1983) \\
\hline \multicolumn{3}{|l|}{ Oise amber (ca. $53 \mathrm{Ma})$} \\
\hline Garypinidae indet. & Garypinidae & Nel et al. (1999), Judson (2009) \\
\hline \multicolumn{3}{|l|}{ Baltic amber (ca. 44-49 Ma) } \\
\hline 7. Feaella (Tetrafeaella) groehni & Feaellidae & Henderickx and Boone (2014) \\
\hline 8. Pseudogarypus extensus & Pseudogarypidae & Beier (1937) \\
\hline 9. Pseudogarypus hemprichii & Pseudogarypidae & Koch and Berendt (1854) \\
\hline 10. Pseudogarypus minor (Rovno amber too) & Pseudogarypidae & Beier (1947), Henderickx et al. (2013) \\
\hline 11. Pseudogarypus pangaea & Pseudogarypidae & Henderickx et al. (2006) \\
\hline 12. Pseudogarypus synchrotron & Pseudogarypidae & Henderickx et al. (2012) \\
\hline 13. Chthonius mengei & Chthoniidae & Beier (1937) \\
\hline 14. Chthonius pristinus & Chthoniidae & Schawaller (1978) \\
\hline Lechytiidae sp. & Lechytiidae? & Poinar et al. (1998); Judson (2005) (phoresy) \\
\hline 15. ${ }^{\mathrm{a}}$ Chelignathus kochii & Tridenchthoniidae & Menge (1854) \\
\hline 16. Microcreagris koellnerorum & Neobisiidae & Schawaller (1978) \\
\hline 17. Neobisium exstinctum & Neobisiidae & Beier (1955) \\
\hline 18. Neobisium henderickxi & Neobisiidae & Judson (2003) \\
\hline Neobisium sp. & Neobisiidae & Beier (1937) \\
\hline 19. Roncus succineus & Neobisiidae & Beier (1955) \\
\hline 20. Cheiridium hartmanni & Cheiridiidae & Menge (1854); Beier $(1937,1953)$ \\
\hline Cheiridium sp. & Cheiridiidae & Schawaller (1978) \\
\hline
\end{tabular}


Table 1. Continued.

\begin{tabular}{|c|c|c|}
\hline & Family & Reference(s) \\
\hline 21. Garypinus electri & Garypinidae & Beier (1937); Judson (2003) (phoresy) \\
\hline 22. Geogarypus gorskii (Rovno amber too) & Geogarypidae & Henderickx (2005) \\
\hline 23. Geogarypus macrodactylus & Geogarypidae & Beier $(1937,1955)$ \\
\hline 24. Geogarypus (?) major & Geogarypidae & Beier (1937) \\
\hline 25. ${ }^{\text {a } O l i g o c h e r n e s ~ b a c h o f e n i ~}$ & Chernetidae & Beier (1937) (phoresy) \\
\hline 26. ${ }^{\text {a } O l i g o c h e r n e s ~ w i g a n d i ~}$ & Chernetidae & Menge (1854), Beier (1937) \\
\hline Unidentified species & Chernetidae & Schlee and Glockner (1978) (phoresy), Beier (1937) \\
\hline 27. ${ }^{\mathrm{a}}$ Dichela berendtii & Cheliferidae & Menge $(1854,1855)$; Beier (1948) (phoresy) \\
\hline 28. ${ }^{\mathrm{a} D i c h e l a ~ g r a c i l i s}$ & Cheliferidae & Beier (1937) \\
\hline 29. ${ }^{\mathrm{a} D i c h e l a ~ g r a n u l a t u s}$ & Cheliferidae & Beier (1937) \\
\hline 30. ${ }^{\mathrm{a}}$ Dichela serratidentatus & Cheliferidae & Beier (1937) \\
\hline 31. ${ }^{\mathrm{a}}$ Electrochelifer bachofeni & Cheliferidae & Beier (1947) \\
\hline 32. ${ }^{\mathrm{a}}$ Electrochelifer balticus & Cheliferidae & Beier (1955), Dashdamirov (2007) \\
\hline 33. ${ }^{\text {a } E l e c t r o c h e l i f e r ~ g r o e h n i ~}$ & Cheliferidae & Dashdamirov (2008) \\
\hline 34. ${ }^{\mathrm{a}}$ Electrochelifer mengei & Cheliferidae & Beier (1937) \\
\hline 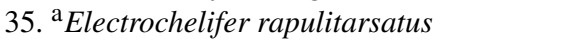 & Cheliferidae & Beier (1947) \\
\hline 36. ${ }^{\text {a Progonatemnus succineus }}$ & Atemnidae & Beier $(1955)$ \\
\hline 37. ${ }^{\mathrm{a}}$ Pycnochelifer kleemanni & Cheliferidae & Koch and Berendt (1854); Beier (1937) (phoresy), Judson (2003) \\
\hline Pycnochelifer sp. & Cheliferidae & Beier (1955) \\
\hline 38. ${ }^{\mathrm{a}}$ Beierowithius sieboldtii & Withiidae & Menge (1854), Beier (1955) \\
\hline Unidentified species & $?$ & Ross (1997) (phoresy) \\
\hline \multicolumn{3}{|l|}{ Rovno amber (ca. 44-49 Ma) } \\
\hline Unidentified species & Chernetidae & Perkovsky et al. (2010) \\
\hline Unidentified species & Cheliferidae & Perkovsky et al. (2010) \\
\hline Pseudogarypus minor (Baltic amber too) & Pseudogarypidae & Beier (1947), Henderickx et al. (2013) \\
\hline Geogarypus gorskii (Baltic amber too) & Geogarypidae & Henderickx and Perkovsky (2012) \\
\hline
\end{tabular}

Romanian amber (ca. 44-49 Ma?)

Unidentified species

$?$

Protescu (1937)

\begin{tabular}{|c|c|c|}
\hline \multicolumn{3}{|l|}{ Bitterfeld amber (ca. 23 Ma?) } \\
\hline Unidentified species & Cheliferidae & Schumann and Wendt (1989) \\
\hline \multicolumn{3}{|l|}{ Dominican amber (ca. 16 Ma) } \\
\hline 39. Pseudochthonius squamosus & Chthoniidae & Schawaller (1980b) \\
\hline 40. Lechytia tertiaria & Lechytiidae & Schawaller (1980b) \\
\hline 41. Pseudochiridium lindae & Pseudochiridiidae & Judson (2007b) \\
\hline 42. Idiogaryops pumilus ${ }^{\mathrm{b}}$ & Sternophoridae & Judson (1998) \\
\hline Americhernes sp. & Chernetidae & Schawaller (1980a) \\
\hline 43. Pachychernes effossus & Chernetidae & Schawaller (1980a) \\
\hline Pachychernes sp. indet. & Chernetidae & Schawaller (1980a) \\
\hline 44. Cryptocheiridium antiquum & Cheiridiidae & Schawaller (1981a) \\
\hline ?Parawithius sp. & Withiidae & Schawaller (1981) \\
\hline Parawithius sp. & Withiidae & Schlee (1980); Schawaller (1981b); \\
\hline & & Poinar (1992); Poinar et al. (1998) (phoresy) \\
\hline Unidentified species & $?$ & Wu (1996) (phoresy) \\
\hline \multicolumn{3}{|l|}{ Chiapas amber, Mexico (ca. 16 Ma) } \\
\hline 45. Paraliochthonius miomaya & Chthoniidae & Judson (2016) \\
\hline Tyrannochthonius sp. indet. & Chthoniidae & Judson (2016) \\
\hline Paratemnoides (?) sp. & Atemnidae & Judson (2016) \\
\hline Lustrochernes (?) sp.1 \& 2 & Chernetidae & Judson (2016) \\
\hline Unidentified species & Chernetidae & Schawaller (1982) \\
\hline Unidentified species & Cheliferidae & Judson (2016) \\
\hline 46. Byrsochernes maatiatus & Chernetidae & Riquelme et al. (2014); Judson (2016) \\
\hline
\end{tabular}


Table 1. Continued.

\begin{tabular}{|c|c|c|}
\hline & Family & Reference(s) \\
\hline \multicolumn{3}{|l|}{ Subfossils } \\
\hline \multicolumn{3}{|l|}{ East African copal } \\
\hline 47. Withius eucarpus & Withiidae & Dalman (1826); Judson (2010) \\
\hline \multicolumn{3}{|l|}{ Madagascan copal } \\
\hline Tyrannchthonius sp. & Chthoniidae & Judson (2010) \\
\hline Deutonymph & Atemnidae & Judson (2010) \\
\hline \multicolumn{3}{|l|}{ Colombian copal } \\
\hline 48. Paratemnoides nidificator ${ }^{\mathrm{b}}$ & Atemnidae & Judson (2010) \\
\hline 49. Pachychernes aff. subrobustus ${ }^{\text {b }}$ & Chernetidae & Judson (2010) \\
\hline
\end{tabular}

al., 2014), which are morphologically conservative if not indistinguishable. The identification of fossil pseudoscorpions has to be based on morphology and invariably requires the detailed study of minute morphological characters such as fine differences of trichobothriotaxy and chaetotaxy. Species identification is difficult if these characters are not accessible. The application of computerised tomographic methods (e.g. Henderickx et al., 2012) has made resolving such details easier, but even this may prove to be of limited value for pseudoscorpion groups known to have a high proportion of cryptic (Recent) species. Essentially, setting species limits in fossil pseudoscorpions is often difficult because morphology is inconclusive or not all necessary characters can be seen.

Since studies of age, relatedness, and stratigraphy of the amber fauna rely heavily on species that are shared between deposits, this reliance on morphology alone may be dangerous. For example, a similar age for the Baltic and Rovno amber faunas could be inferred from the similarities between the two species of a pseudogarypid and pseudogeogarypid, respectively. However, both groups today contain species that are difficult to distinguish morphologically and often have naturally small ranges (Benedict and Malcolm, 1978; Harvey, 1986). Similarly, an extant species in the family Sternophoridae has been described from Miocene amber (Judson, 1998) but this would imply that a single species has remained in morphological stasis for at least 16 million years. This is of course possible but does not exclude the alternative hypothesis of having two cryptic species in different time periods. Hence, we urge caution when suggesting conspecificity of samples across different time periods and geographically distinct deposits.

Foss. Rec., 20, 215-238, 2017

\subsection{Biogeography}

\subsubsection{Burmese amber records}

Perhaps the most important contribution of the amber fossils lies in providing information about the Mesozoic-Cenozoic faunal composition in a given geographical area and the assessment of palaeoclimatic shifts. Many pseudoscorpion lineages today are restricted to specific climates or biogeographic areas and thus it is interesting to compare current distribution patterns with the fossil faunas. Relatively little can be said about the biogeography of the Burmese amber pseudoscorpion fauna because it is incompletely documented. Nevertheless, the known fossils largely mirror a fauna that is still found in South East Asia with taxa that are common in tropical or subtropical regions, often with very wide distributions. Protofeaella peetersae does not appear to be similar to any of the known species from the Australian fauna (Harvey et al., 2016) or Indo-Madagascar and Malaysia. In any case, the fossil extends the known range of its family, Feaellidae (see also below) and may provide further evidence for the Gondwanan connection of the Malay Peninsula (including parts of Myanmar) via the Cimmerian palaeocontinent. This was recently suggested as underlying current distributions in the harvestman family Stylocellidae (Clouse and Giribet, 2010). It is important to mention that additional pseudoscorpion fossils from Burmese amber await description, including additional species of Feaellidae in the collections of professional dealers, and further biogeographic patterns of interest may emerge when this fauna is documented further.

\subsubsection{Baltic amber records}

Most data can be gleaned from the rich Baltic amber pseudoscorpion fauna, which is characterised by many lineages that are today restricted to tropical or Mediterranean climates. In detail, Baltic amber includes members in the 
Table 2. Summary of the higher systematics of the pseudoscorpions down to family level, indicating those groups with a known fossil record and their oldest stratigraphic ages. Sequence of families reflects the phylogeny of Harvey (1992). The same data are represented graphically in Fig. 3. The Epiocheirata are in quotation marks because this group probably represents a paraphyletic assemblage according to the most recent phylogeny for the order (Murienne et al., 2008).

\begin{tabular}{|c|c|c|c|}
\hline Taxon & Oldest record & Age (Ma) & Oldest species \\
\hline \multicolumn{4}{|l|}{ Pseudoscorpiones } \\
\hline Stem group & Devonian (Givetian) & 390 & Dracochela deprehendor \\
\hline Crown group & Cretaceous (late Albian) & 100 & \\
\hline "Epiocheirata" & Cretaceous (Cenomanian) & 99 & \\
\hline Feaelloidea & Cretaceous (Cenomanian) & 99 & \\
\hline Feaellidae & Cretaceous (Cenomanian) & 99 & Protofeaella peetersae \\
\hline Pseudogarypidae & Eocene (Lutetian) & 49 & Pseudogarypus hemprichii \\
\hline Chthonioidea & Eocene (Lutetian) & 49 & \\
\hline Chthoniidae & Eocene (Lutetian) & 49 & Chthonius mengei \\
\hline Pseudotyrannochthoniidae & - & - & - \\
\hline Lechytiidae & Miocene (Burdigalian) & 16 & Lechytia tertiaria \\
\hline Tridenchthoniidae & Eocene (Lutetian) & 49 & Chelignathus kochii \\
\hline Iocheirata & Cretaceous (late Albian) & 100 & \\
\hline Neobisioidea & Eocene (Lutetian) & $49-44$ & \\
\hline Bochicidae & - & - & - \\
\hline Gymnobisiidae & - & - & - \\
\hline Hyidae & - & - & - \\
\hline Ideoroncidae & Cretaceous (Cenomanian) & $99 ?$ & Ideoroncidae (?) indet. (this study) \\
\hline Neobisiidae & Eocene (Lutetian) & 49 & - \\
\hline Parahyidae & - & - & - \\
\hline Syarinidae & - & - & - \\
\hline Cheiridoidea & Cretaceous (Cenomanian) & 99 & \\
\hline Cheiridiidae & Cretaceous (Cenomanian) & 99 & Electrobisium acutum \\
\hline Pseudochiridiidae & Miocene (Burdigalian) & 16 & Pseudochiridium lindae \\
\hline Garypoidea & Cretaceous (Cenomanian) & 99 & \\
\hline Garypidae & - & - & - \\
\hline Garypinidae & Cretaceous (Cenomanian) & 99 & Amblyolpium burmiticum \\
\hline Geogarypidae & Eocene (Lutetian) & $49-44$ & Geogarypus marodactylus \\
\hline Larcidae & - & - & - \\
\hline Menthidae & - & - & - \\
\hline Olpiidae & - & - & - \\
\hline Sternophoroidea & Miocene (Burdigalian) & 16 & \\
\hline Sternophoridae & Miocene (Burdigalian) & 16 & Idiogaryops pumilus \\
\hline Cheliferoidea & Cretaceous (late Albian) & 100 & \\
\hline Atemnidae & Eocene (Lutetian) & 49 & Progonatemnus succineus \\
\hline Chernetidae & Cretaceous (Campanian) & 84 & Chernetidae sp. indet. (juvenile) \\
\hline Cheliferidae & Cretaceous (late Albian) & 100 & Heurtaultia rossiorum \\
\hline Withiidae & Eocene & 49 & Beierowithius sieboldi \\
\hline
\end{tabular}

families Atemnidae, Garypinidae, Geogarypidae, and Tridenchthoniidae that only occur today in Europe in the Mediterranean basin and the Balkans (Harvey, 2011). This pattern is also evident at genus level, with the neobisiid genus Roncus being present in Baltic amber (Beier, 1955) and very speciose today in Mediterranean countries such as Italy, southern France, and Spain. By contrast, no Roncus species are known from Germany, Poland, or eastern Russia where the amber is sourced.

Of considerable biogeographic interest is the presence of the basal pseudoscorpion genus Pseudogarypus in Baltic amber (Beier, 1937, 1947). Today Pseudogarypidae has a bipolar distribution, with six species of Pseudogarypus in North America (Benedict and Malcolm, 1978; Harvey and Štáhlavský, 2010) and one additional species of Neopseudogarypus in Tasmania. This distribution suggests a former Pangaean distribution, and in this context it is interesting that five additional fossil species of Pseudogarypus are known from Baltic amber (Table 1; see also Henderickx et al., 2012), indicating a formerly diverse fauna in Europe that became extinct sometime after the Eocene. Similar patterns of past extinction may be present in the neobisoid genus Microcrea- 
gris, which is present in Baltic amber (Schawaller, 1978) but does not occur in Europe today, while being species-rich in North America and Asia. The genus Cheiridium is known in Baltic amber with two species, but apart from the cosmopolitan Cheiridium museorum, members of this genus are restricted today to tropical or subtropical biomes.

Perhaps of greatest interest is the recent description of Feaella groehni from Baltic amber sourced near Kaliningrad (Henderickx and Boone, 2014) and this is for two reasons. First of all, Feaellidae today have a disjunct distribution on former Gondwanan landmasses and species are known from tropical or subtropical climates in continental Africa, Brazil, Madagascar, Sri Lanka, India, and Australia, with some recent records established for South East Asia (Harvey, 2013; Judson, 2017). Feaella groehni would extend the known range of this family into former Laurasian land masses in Europe and at the same time indicate past extinction in the Northern Hemisphere. The same pattern that has been inferred for other arachnid groups, such as archaeid spiders, which only occur today on Gondwanan land masses but are known as fossils in Baltic amber and compression fossils from China (Wood et al., 2012). Secondly, the pseudoscorpion data may indicate former sympatry of two sister families that exclude each other today because of differences in climatic preferences. Pseudogarypidae is known today only from temperate climates, while Feaellidae is known today only from warm climates (Fig. 4). Assuming there were no shifts in the climatic tolerances of these groups since the Eocene, this would indicate that temperatures in the Baltic amber forest may have changed over time or that this forest was strongly heterogeneous over its geographic extent. Data derived from both insects and other arachnids indicate that the Baltic amber forest thrived under warmer conditions than today and there are many other examples, e.g. camel spiders in the family Solifugae that are preserved in Baltic amber (Dunlop et al., 2004; Dunlop and Klann, 2009) but only occur in Mediterranean climates throughout Europe today. However, this cannot explain the diversity and apparent abundance of Pseudogarypus that prefer colder climates and this may hint to a complex climatic history or problems in the stratigraphic record.

Despite these controversies, the pseudoscorpion fauna in Baltic amber generally indicates warmer conditions in the amber forest than today, perhaps comparable with modern Mediterranean climates. It is evident that there have been significant compositional shifts since this amber was deposited, leading either to the total extinction of some groups in Europe (e.g. Pseudogarypus) or the restriction of taxa to wellknown glacial refugia (e.g. Roncus) such as the Mediterranean basin and the Balkans where these lineages persist but have not recolonised central Europe following the last glacial episodes (e.g. Schmitt, 2007). Again, we should mention an apparent taxonomic connection between the Baltic pseudoscorpions and those in Rovno amber given that morphospecies are shared between these deposits (Henderickx and Perkovsky 2012; Henderickx et al., 2013), which are more than $570 \mathrm{~km}$ apart. Considering that the amber is most likely of similar age, this may indicate a much wider distribution of the amber forest across eastern Europe in the Eocene, right down to the Black Sea, which was then widely connected to the ocean.

\subsubsection{Neotropical amber records}

The comparably modern Dominican and Mexican amber faunas also illustrate a tropical pseudoscorpion fauna with species in genera that still occur in these areas today. Seven families are currently known from Dominican amber and six of these are recorded from this region today, with the additional genus Cryptocheiridium known from neighbouring Cuba (Harvey, 2013). The Dominican amber fauna comprises the almost cosmopolitan genera Paraliochthonius and Tyrannochthonius, as well as the widespread Paratemnoides and Lustrochernes, which is widespread, with several species in Central America today. Paraliochthonius is a pseudoscorpion genus with species restricted to intertidal zones and mangroves, which may indicate that the amber was deposited in comparably moist conditions. Too little is known about the remaining amber faunas to speculate on biogeographic patterns.

\subsection{Palaeoecology}

As noted above, most fossil pseudoscorpions derive from amber, which in turn is fossilised tree resin. With respect to the original palaeoenvironment, amber obviously introduces a sampling bias towards taxa living close to the amber source. These animals were more likely to have been trapped in the sticky resin. For pseudoscorpions this means we would expect to predominantly find taxa, which are arboreal and/or corticolous, i.e. found on (or under) tree bark. We can observe a prevalence of the bark-associated families Atemnidae, Cheliferidae, and Chernetidae in the superfamily Cheliferoidea (Table 1), whereas leaf litter forms such as Chthoniidae and Neobisiidae are comparably rare. In the Baltic amber alone, 12 species of Cheliferidae have been described so far, whereas only six species are shared between the Chthoniidae and Neobisiidae. This bias was first noted by Beier (1937) and is almost certainly caused by the nature of the resin and the ecology of groups that have a high probability of coming into contact with it. Atemnidae, Cheliferidae, and Chernetidae are typically associated with living or decomposing tree bark in modern ecosystems. By contrast only one of the currently seven recognised families in the litter- and soil-dwelling superfamily Neobisiidae are known from fossils, and there are currently no fossils for the families Bochicidae, Gymnobisiidae, Hyidae, Parahyidae, and Syarinidae (Table 1) even though at least some of these families are species-rich in warm climates today. Also absent are groups that occur preferentially in littoral or arid envi- 
ronments in which families such as the Garypidae and the Olpiidae are typically found under rocks. We should note that because pseudoscorpions can be carried by other arthropods (see section "Phoresy"), this does introduce the possibility that taxa from non-arboreal habitats may be accidentally transported into amber attached to their flying hosts.

While Dracochela lacked spinnerets, the ability to spin silk is certainly present in the younger amber fossils and some inclusions - such as a Cheiridium hartmanni - were preserved whilst excreting silk from the galea (Beier, 1937). There are also no obvious differences in breeding biology between the Eocene fossils and Recent forms. A fossil Pycnochelifer kleemanni was preserved with a disk of eggs (Beier, 1937), which is typical for extant members of the Cheliferidae today. Generally, there is no indication of behavioural or ecological shifts when comparing amber fossils to Recent forms, which may reflect the relative stability of the environments in which these arachnids occur.

\section{Phoresy}

Pseudoscorpions are well known today for practising phoresy and members of several families (see e.g. Judson, 2005) have been documented attaching themselves as hitchhikers to larger arthropods and using them as a means of transport. Phoresy in both living and fossil species was reviewed by Poinar et al. (1998). Several examples of fossil pseudoscorpions attached to their host have been documented in both Baltic and Dominican amber (Table 1). There are actually many cases that document this behaviour because phoretic pseudoscorpions usually occur in ephemeral habitats, such as under bark, whereas the leaf litter fauna is not phoretic. This again contributes towards a general bias in the fossil data towards bark-associated faunas.

Historically, the oldest record of phoresy was by Menge (1855), who reported his Baltic amber species Dichela berendtii phoretic on an unidentified parasitoid wasp (Hymenoptera: Ichneumonidae). The same pseudoscorpion species was also found by Beier (1948) on an unidentified caddis fly (Trichoptera). Beier (1937) documented both Oligochernes bachofeni and Pycnochelifer kleemanni on unidentified species of another parasitoid wasp family in Baltic amber (Hymenoptera: Braconidae). A member of the family Chernetidae was found phoretic on a crane fly (Diptera: Tipulidae) by Schlee and Glockner (1978) and an unidentified pseudoscorpion was discovered on another Baltic amber fly, Chrysothemis speciosa Loew, 1850 (Diptera: Rachiceridae) by Ross (1997). Poinar et al. (1988) themselves figured a supposed example of a Chthonius sp. on an unidentified moth (Lepidoptera) in Baltic amber. However, this record should be treated with caution as chthoniids today are not phoretic and Judson (2005) commented that the figured fossil looks more like a member of the family Lechytiidae, in which case it would be the oldest record of the family that is otherwise only known in Dominican am- ber. In the same paper, Judson (2003) described an example of Garypinus electri in Baltic amber attached to the leg of a tipuloid fly, a behaviour that has yet to be reported from extant species of this family. Judson (2003) predicted that phoresy could be even older than the Eocene, as some of the Cretaceous amber pseudoscorpions belong to families known to be phoretic today. He also stressed that comparing the distribution of this behaviour to the known phylogenetic trees suggests that phoresy may have arisen independently up to five times within the pseudoscorpions, possibly as an adaptation to help the animals disperse to or from ephemeral or unstable habitats.

In Dominican amber several authors (Schlee, 1980; Schawaller, 1981b; Poinar, 1992) reported a possible Parawithius sp. phoretic on the ambrosia beetle Cenocephalus rhinoceroides (Schawaller, 1981) (Coleoptera: Platypodidae). Modern members of this genus are also known to be phoretic on a number of Neotropical beetles; see e.g. Poinar et al. (1988: Table 2) and references therein. Finally, an unidentified pseudoscorpion was reported by $\mathrm{Wu}$ (1996) on the stingless bee Proplebeia dominicana Wille and Chandler, 1964 (Hymenoptera: Apidae) in Dominican amber. As listed by Poinar et al. (1988), extant bees are known to carry a number of living pseudoscorpion genera. It is not surprising that all the lineages that were reported as phoretic in amber still show this ecology today. As noted above, they typically represent pseudoscorpion faunas associated with ephemeral habitats. More families of pseudoscorpions are documented to be phoretic today (e.g. the Atemnidae), but no fossils revealing this behaviour are currently known. It should also be noted that the Devonian Dracochela deprehendor is not a member of this ecological group and probably lived in leaf litter. We suspect that it is unlikely to have been phoretic, and it remains unclear when exactly phoresy evolved in pseudoscorpions for the first time.

\section{Perspectives}

A survey of the literature reveals there are several potentially interesting sources of further data, in particular, undescribed pseudoscorpions from Burmese, Lebanese, Álava, Indian, New Jersey, and Bitterfeld amber. Describing the fossils so far only mentioned or illustrated in the literature would be a worthwhile task. It would help to characterise the arthropod palaeocommunities of these deposits and the evolution of these arthropod faunas in these regions over time and identify the effects of palaeoclimatic shifts on soil faunas more generally. At the same time most of the species records are associated with Baltic amber, but other than the synonymy identified by Judson (2003) there has been no systematic revision of the Baltic amber fauna. This appears necessary but may be difficult to implement for the reasons discussed above. 
It would obviously be useful to fill in the gap of more than 260 million years between the Devonian compression fossils and the Cretaceous amber faunas, during which crowngroup pseudoscorpions evolved and diversified. The considerable difficulties with dating pseudoscorpion phylogenies (and arachnid phylogenies in general) stem from such gaps in the fossil record and pseudoscorpions are a prime example of a fauna that is ancient but does not fossilise easily in nonamber deposits. It may yet be possible to push the origins of Pseudoscorpiones even further back from the mid-Devonian. The unique and unusual morphology of pseudoscorpions must have evolved before this time, perhaps in the Silurian from which the oldest arachnid fossils are known.

Finally, it should be noted that 10 pseudoscorpion families (Table 2) have yet to be described or discovered as fossils, in particular groups that have a more tropical distribution and do not occur under bark (e.g. Garypidae, Hyidae, and Olpiidae). Some undocumented groups have interesting present-day distributions such as Hyidae with a western Gondwanan distribution that spans Australia, Madagascar, India, Sri Lanka, and South East Asia (Harvey and Volschenk, 2007; Harvey et al., 2017). Establishing a fossil record for such families may reveal further insights into their evolution and establish whether present-day distributions are indeed the outcome of continental drift and vicariance as one would expect. All of this data could help to build a picture of past extinction and range shifts in response to biotic changes among these ancient arachnids and provide broader insights into the evolution of arthropod faunas over time.

Data availability. All figured specimens are in publically available collections.

Competing interests. The authors declare that they have no conflict of interest.

Acknowledgements. We thank Thure Dalsgaard (CeNak, Zoological Museum) for imaging the fossil pseudoscorpions in amber with great skill and patience, Ulrich Kotthoff (CeNak, Geologisch-Paläontologisches Institut) for the loan of Baltic amber types in his collection, Karin Wolf-Schwenninger (SMNS) for the loan of Chthonius pristinus and Microcreagris koellneri, Christoph Hörweg (NHW) for information on the deposition of some old pseudoscorpion types from the Bachofen-Echt collection, and Carsten Gröhn (Hamburg) for permission to use his images of Feaella and Pseudogarypus. Paul Selden and an anonymous reviewer kindly provided feedback on an early version of this paper.

Edited by: Torsten Scheyer

Reviewed by: Paul Selden and one anonymous referee

\section{References}

Arabi, J., Judson, M. L., Derharveng, L., Lourenço, W. R., and Hassanin, A.: Nucleotide composition of CO1 sequences in Chelicerata (Arthropoda): detecting new mitochondrial rearrangements, J. Mol. Evol., 74, 81-95, 2012.

Balzan: Chernetidae nonnullae Sud-Americanae, III. Asuncion, 1888.

Balzan: Voyage de M. E. Simon au Venezuela (Décembre 1887Avril 1888), Arachnides, Chernetes (Pseudoscorpiones), Annales de la Société Entomologique de France, 60, 497-552, 1992.

Bartel, C., Konikiewicz, M., Mąkol, J., Wohltmann, A., and Dunlop, J. A.: Smaridid mites in Baltic and Bitterfeld amber, with notes on the fossil record of terrestrial Parasitengona (Trombidiformes: Prostigmata), Annal. Zool., 65, 641-659, 2015.

Beier, M.: Pseudoscorpionidea I. Subord. Chthoniinae et Neobisiinae, Das Tierreich, 57, 1-258, 1932a.

Beier, M.: Pseudoscorpionidea II. Subord. C. Cheliferinea, Das Tierreich, 58, 1-294, 1932b.

Beier, M.: Pseudoscorpione aus dem baltischen Bernstein, Festschr. 60. Geburt. Prof. Dr. Embrik Strand, Riga, 2, 302-316, 1937.

Beier, M.: Pseudoskorpione im Baltischen Bernstein und die Untersuchung von Bernstein-Einschlüssen, Mikroscopie, Wien, 1, 188-199, 1947.

Beier, M.: Phoresie und Phagophilie bei Pseudoscorpionen, Österr. Zool. Zeitschr., 1, 441-497, 1948.

Beier, M.: Pseudoscorpione im baltischen Bernstein aus dem Geologischen Staatsinstitut in Hamburg, Mitteil. Min.-Geol. Staatsinst. Hamburg, 25, 48-54, 1955.

Benedict, E. M. and Malcolm, D. R.: The family Pseudogarypidae (Pseudoscorpionida) in North America with comments on the genus Neopseudogarypus Morris from Tasmania, J. Arachnol., 6, 81-104, 1978.

Braun, A.: Vorkommen, Untersuchungsmethoden und Bedeutung tierische Cuticulae in Kohligen Sedimentgesteinen des Devons und Karbons, Palaeontograph. A, 245, 83-156, 1997.

Chamberlin, J. C.: The arachnid order Chelonethida, Stanford Uni. Pub., Biol. Sci., 7, 1-284, 1931.

Clouse, R. M. and Giribet, G.: When Thailand was an island the phylogeny and biogeography of mite harvestmen (Opiliones, Cyphophthalmi, Stylocellidae) in Southeast Asia, J. Biogeog., 37, 1114-1130, 2010.

Clouse, R. M., Sharma, P. P., Stuart, J. C., Davis, L. R., Giribet, G., Boyer, S. L., and Wheeler, W. C.: Phylogeography of the harvestmen genus Metasiro (Arthropoda, Arachnida, Opiliones) reveals a potential problem to the Pangaean paradox, Org. Div. Evol., 16, 167-184, 2016.

Cockerell, T. D. A.: Arthropods in Burmese amber, Am. J. Sci., ser. 4, 44, 360-368, 1917.

Cockerell, T. D. A.: Fossil arthropods in the British Museum. I, Ann. Mag. Nat. Hist., ser. 9, 5, 273-279, 1920.

Cohen, K. M., Finney, S. C., Gibbard, P. L., and Fab, J.-X.: The ICS International Chronostraigraphic Chart, Episodes 36, 199-204, 2013 (updated).

Corda, A. J. C.: Über eine fossile Gattung der Afterscorpione, Verhand. Gesell. Vaterländ. Mus. Böhmen, Prag, 14-18, 1839.

Crowson, R. A., Rolfe, W. D. I., Smart, J., Waterston, C. D., Willey, E. C., and Wooton, R. J.: Arthropoda: Chelicerata, Pycnogonida, Palaeoisopus, Myriapoda and Insecta, in: The Fossil Record, Geological Society of London, London, 499-534, 1967. 
Dalman, J. W.: Om Insekter inneslutne I Copal, jemte beskrifning på några deribland förekommande nya slägten och arter, Kung. Sven. Vetenskapsakad. Hand., 46, 375-410, 1826.

Dashdamirov, S.: A new species of false scorpion from Baltic amber with a redescription of Electrochelifer balticus Beier, 1955 and remarks on some fossil Cheliferidae (Arachnida: Chelonethida), Acta Biol. Benrodis, 14, 1-13, 2008.

Delclòs, X., Arillo, A., Peñalver, E., Barrón, E., Soriano, C., López del Valle R., Bernárdez, E., Corral, C., and Ortuño, V. M.: Fossiliferous amber deposits from the Cretaceous (Albian) of Spain, Com. Rend. Palevol, 6, 135-149, 2007.

Dunlop, J. A.: Arácnidos fósiles (con exclusión de arañas y escorpiones), in: Volumen Monográfico: PaleoEntomologica, edited by: Melic, A., Bol. Soc. Entomol. Aragonesa, 16, 77-92, 1996 (in Spanish and English).

Dunlop, J. A.: Palaeontology, in: Pinto-da-Rocha, R., edited by: Machado, G. and Giribet, G., Harvestmen, The Biology of Opiliones, Harvard University Press, Cambridge, 247-265, 2007.

Dunlop, J. A.: Geological history and phylogeny of Chelicerata, Arth. Struc. Develop., 39, 124-142, 2010.

Dunlop, J. A. and Klann, A. E.: A second camel spider (Arachnida: Solifugae) from Baltic amber, Acta Geol. Polon., 59, 3944, 2009.

Dunlop, J. A. and Penney, D.: Fossil arachnids. Siri Scientific Press, Manchester, 2012.

Dunlop. J. A., Wunderlich, J., and Poinar Jr., G. O.: The first fossil opilioacariform mite (Acari: Opilioacariformis) and the first Baltic amber camel spider (Solifugae), Trans. R. Soc. Edinburgh: Earth Sci., 94, 261-273, 2004.

Dunlop, J. A., Penney, D., and Jekel, D.: A summary list of fossil spiders and their relatives, in: World Spider Catalog, Natural History Museum Bern, available at: http://wsc.nmbe.ch, version 17.5, last access: April 2017.

Ellingsen, E.: Die Pseudoskorpione des Berliner Museums, Mitteilung aus dem Zoologischen Museum in Berlin, 4, 357-423, 1910.

Gao, Z., Zhang, F., and Harvey, M. S.: A modified definition of the genus Haplochernes (Pseudoscorpiones: Chernetidae), with a new species from Hainan Island, J. Arachnol., 45, 112-122, 2017.

Geinitz, H. B.: Kreischeria wiedei, ein Pseudoskorpion aus der Steinkohlenformation von Zwickau, Z. Deutsch. Geol. Gesell., 34, 238-242, 1882.

Grimaldi, D. A.: Amber: Window to the Past, American Museum of Natural History, H. N. Abrams Inc., New York, 1996.

Grimaldi, D. A., Engel, M. S., and Nascimbene, P. C.: Fossiliferous Cretaceous amber from Myanmar (Burma): its rediscovery, biotic diversity, and paleontological significance, Am. Mus. Novit., 3361, 1-71, 2002.

Gröhn, C.: Bernstein-Abenteuer Bitterfeld, Books on demand $\mathrm{GmbH}$, Norderstedt, 2010.

Harrison S. E., Guzik M. T., Harvey M. S., and Austin A. D.: Molecular phylogenetic analysis of Western Australian troglobitic chthoniid pseudoscorpions (Pseudoscorpiones: Chthoniidae) points to multiple independent subterranean clades, Invert. Syst., 28, 386-400, 2014.

Harvey, M. S.: The Australian Geogarypidae, new status, with a review of the generic classification (Arachnida: Pseudoscorpionidea), Aust. J. Zool., 34, 753-778, 1986.
Harvey, M. S.: Catalogue of the Pseudoscorpionida, Manchester University Press, Manchester \& New York, 1991.

Harvey, M. S.: The phylogeny and classification of the Pseudoscorpionida (Chelicerata: Arachnida), Invert. Syst., 6, 1373-1435, 1992.

Harvey, M. S.: Order Pseudoscorpiones de Geer, 1778, in: Animal biodiversity: An outline of higher-level classification and survey of taxonomic richness, edited by: Zhang, Z.-Q., Zootaxa, 3148, 119-120, 2011.

Harvey, M. S.: Pseudoscorpions of the World, version 3.0. Western Australian Museum, Perth, available at: http://www.museum.wa. gov.au/catalogues/pseudoscorpions (last access: March 2017), 2013.

Harvey, M. S. and Štáhlavský, F.: A review of the pseudoscorpion genus Oreolpium (Pseudoscorpiones: Garypinidae), with remarks on the composition of the Garypinidae and on pseudoscorpions with bipolar distributions, J. Arachnol., 38, 294-308, 2010.

Harvey, M. S. and Volschenk, E. S.: Systematics of the Gondwanan pseudoscorpion family Hyidae (Pseudoscorpiones: Neobisioidea): new data and a revised phylogenetic hypothesis, Invert. Syst., 21, 365-406, 2007.

Harvey, M. S., Andrade, R., and Pinto-Da-Rocha, R.: The first New World species of the pseudoscorpion family Feaellidae (Pseudoscorpiones: Feaelloidea) from the Brazilian Atlantic Forest, J. Arachnol., 44, 227-234, 2016.

Harvey, M. S., Rix, M. G., Harms, D., Giribet, G., Vink, C. J., and Walter, D. E.: The biogeography of Australasian arachnids, in: Ebach, M. (ed.) Handbook of Australasian Biogeography, CRC Press, Boca Raton, FL, 241-267, 2017.

Henderickx, H.: A new Geogarypus from Baltic amber (Pseudoscorpiones: Geogarypidae), Phegea, 33, 87-92, 2005.

Henderickx, H. and Boone, M.: The first fossil Feaella Ellingsen, 1906, representing an unexpected pseudoscorpion family in Baltic amber (pseudoscorpiones, Feaellidae), Entomo-Info, 25, 5-11, 2014.

Henderickx, H. and Boone, M.: The basal pseudoscorpion family Feaellidae Ellingsen, 1906 walks the Earth for 98.000 .000 years: a new fossil genus has been found in Cretaceous Burmese amber (Pseudoscorpiones: Feaellidae), Entomo-Info, 27, 7-12, 2016.

Henderickx, H. A. and Perkovsky, E. E.: The first geogarypid (Pseudoscorpiones, Geogarypidae) in Rovno Amber (Ukraine), Vest. Zool., 46, 273-276, 2012.

Henderickx, H., Cnudde, V., Masschaele, B., Dierick, M., Vlassenbroeck, J., and van Hoorebeke, L. : Description of a new fossil Pseudogarypus (Pseudoscorpiones: Pseudogarypidae) with the use of X-ray micro-CT to penetrate opaque amber, Zootaxa, 1305, 41-50, 2006.

Henderickx, H., Tafforeau, P., and Soriano, C.: Phase contrast synchrotron microtomography reveals the morphology of a partially visible new Pseudogarypus in Baltic amber (Pseudoscorpiones: Pseudogarypidae), Palaeont. Electron., 15, 17A, 11 pp., 2012.

Henderickx, H., Perkovsky, E. E., Van Hoorebeke, L., and Boone, M.: The first pseudogarypid in Rovno amber (Ukraine) (Pseudoscorpiones: Pseudogarypidae), Phegea, 41, 90-92, 2013.

Hirst, S.: On some arachnid remains from the Old Red Sandstone (Rhynie Chert bed, Aberdeenshire), Ann. Mag. Nat. Hist., Ser. 9, 12, 455-474, 1923.

Hoff, C. C.: Sternophorid pseudoscorpions, chiefly from Florida, Am. Mus. Novit., 2150, 1-14, 1963. 
Hong Y.-C.: [Discovery of new fossil pseudoscorpionids in amber], Bull. Tianjin Inst. Geol. Mineral Resources, 8, 24-29, 1983 (in Chinese with English summary).

Hope, F. W.: Observations on the fossil insects of Aix in Provence, with descriptions and figures of three species, Trans. Entomol. Soc. London, 4, 250-255, 1847.

Jeram, A. J.: Scorpions from the Viséan of East Kirkton, West Lothian, Scotland, with a revision of the infraorder Mesoscorpionina, Trans R. Soc. Edinburgh: Earth Sci., 84, 283-299, 1994a.

Jeram, A. J.: Carboniferous Orthosterni and their relationship to living scorpions, Palaeontology, 37, 513-550, 1994b.

Judson, M. L. I.: African Chelonethi: studies on the systematics, biogeography and natural history of African pseudoscorpions, Index to theses, with abstracts, accepted for higher degrees by the universities of Great Britain and Ireland, 42, 697, 1993.

Judson, M. L. I.: A strenophorid pseudoscorpion (Chelonethi) in Dominican amber, with remarks on the family, J. Arachnol., 26, 419-428, 1998.

Judson, M. L. I.: Electrobisium acutum Cockerell, a cheiridiid pseudoscoprion from Burmese amber, with remarks on the validity of the Cheiridioidea (Arachnida, Chelonethi), Bull. Nat. Hist. Mus., Lond. (Geol.), 56, 79-83, 2000.

Judson, M. L. I.: Baltic amber pseudoscorpions (Arachnida: Chelonethi): a new species of Neobisium (Neobisiidae) and the status of Obisium rathkii Koch and Berendt, Geodiversitas, 25, 445450, 2003.

Judson, M. L. I.: Baltic amber fossil of Garypinus electri Beier provides first evidence of phoresy in the pseudoscorpion family Garypinidae (Arachnida: Chelonethi), European Arachnol., 2003, 127-131, 2005.

Judson, M. L. I.: A new and endangered species of the pseudoscorpion genus Lagynochthonius from a cave in Vietman, with notes on chelal morphology and the composition of the Tyrannochthoniini (Arachnida, Chelonethi, Chthoniidae), Zootaxa, 1627, 53-68, 2007a.

Judson, M. L. I.: First fossil record of the pseudoscorpion family Pseudochiridiidae (Arachnida, Chelonethi, Cheirioidea) from Dominican amber, Zootaxa, 1393, 45-51, 2007b.

Judson, M. L. I.: Cheliferoid pseudoscorpions (Arachnida, Chelonethi) from the Lower Cretaceous of France, Geodiversitas, 31, 61-71, 2009.

Judson, M. L. I.: Redescription of Chelifer eucarpus Dalman (Arachnida, Chelonethi, Withiidae) and first records of pseudoscorpions in copal from Madagascar and Colombia, Palaeodiversity, 3, 33-42, 2010.

Judson, M. L. I.: Reinterpretation of Dracochela deprehendor (Arachnida: Pseudoscorpiones) as a stem-group pseudoscorpion, Palaeontology, 55, 261-283, 2012.

Judson, M. L. I.: Pseudoscorpions (Arachnida, Chelonethi) in Mexican amber, with a list of extant species associated with mangrove and Hymenaea trees in Chiapas, Bol. Soc. Geol. Mexicana, 68, 57-79, 2016.

Judson, M. L. I.: A new subfamily of Feaellidae (Arachnida, Chelonethi, Feaelloidea) from Southeast Asia, Zootaxa, 4258, 1-33, 2017.

Keilbach, R.: Bibliographie und Liste der Arten tierischer Einschlüsse in fossilen Harzen sowie ihrer Aufbewahrungsorte, Dtsch. Entomol. Z., 29, 129-286, 1982.
Kjellesvig-Waering, E. N.: A restudy of the fossil Scorpionida of the world, Palaeontograph. Am., 55, 1-287, 1986.

Koch, C. L. and Berendt, G. C.: Die im Bernstein befindlichen Myriapoden, Arachniden und Apteren der Vorwelt, in: , Die in Bernstein befindlichen organischen Reste der Vorwelt gesammelt in Verbindung mit mehreren bearbeitetet und herausgegeben 1, edited by: Berendt, G. C., Berlin, Nicolai, 124 pp., 1854.

Menge, A.: Footnotes in Koch, C. L. \& Berendt, G. C.: Die im Bernstein befindlichen Myriapoden, Arachniden und Apteren der Vorwelt, in: Die in Bernstein befindlichen organischen Reste der Vorwelt gesammelt in Verbindung mit mehreren bearbeitetet und herausgegeben 1, edited by: Berendt, G. C., Berlin, Nicolai, 124 pp., 1854.

Menge, A.: Über die Scherenspinnen, Chernetidae. Schrf. Naturf. Ges. Danzig, 5, 1-41, 1855.

Muchmore, W. B.: Ecology of pseudoscorpions - a review, Proc. First Soil Microcommunities Conference, Syracuse, NY, 121127, 1973.

Murienne, J., Harvey, M. S., and Giribet, G.: First molecular phylogeny of the major clades of Pseudoscorpiones (Arthropoda: Chelicerata), Mol. Phylo. Evol., 49, 170-184, 2008.

Murienne, J., Daniels, S. R., Buckley, T. R., Mayer, G., and Giribet, G.: A living fossil tale of Pangaean biogeography, Proc. R. Soc. B: Biol. Sci., 281, 20132648, 2013.

Nel, A., Plöeg, G. de., Dejax, J., ., Dutheil, D., de Franceschi, D., Gheerbrant, E., Godinot, M., Hervet, S., Menier, J.-J., Ague, M., Bignot, G., Cavagnetto, C., Duffard, S., Gaudant, J., Hua, S., Jpssang, A., de Lapparent de Broin, F., Pozzi, J.-P., Paicheler, J.C., Beuchet, F., and Rage, J.-C.: Un gisement sparnacien exceptionnel à plantes, arthropodes et vertébrés (Éocène basal, MP7): Le Quesnoy (Oise, France), C. R. Acad. Sci.-Series IIA - Earth and Planetary Sci., 329, 65-72, 1999.

Nury, D.: L'Oligocène de Provence Méridionale, Doc. Bureau de Rech. Géol. et Min., 163, 1-411, 1990.

Penney, D.: Dominican Amber Spiders, Siri Scientific Press, Manchester, UK, 2008.

Perkovsky, E. E., Rasnitsyn, A. P., Vlaskin, A. P., and Taraschuk, M. V.: A comparative analysis of the Baltic and Rovno amber arthropod faunas: representative samples, Afr. Invert., 48, 229245, 2007.

Perrichot, V.: Early Cretaceous amber from south-western France: insights into the Mesozoic litter fauna, Geol. Acta, 2, 9-22, 2004.

Peterson, A. T., Soberón, J., and Sánchez-Cordero, V.: Conservationism of ecological niches in evolutionary time, Science, 285 , 1265-1267, 1999.

Petrunkevitch, A. I.: Palaeozoic and Mesozoic Arachnida of Europe, Mem. Geol. Soc. America, 53, 1-128, 1953.

Petrunkevitch, A. I.: Arachnida, in: Treatise on Invertebrate Paleontology, Part P, Arthropoda 2, edited by: Moore, R. C., Geological Society of America, Boulder, and University of Kansas Press, Lawrence, 42-162, 1955.

Poinar Jr., G. O.: Life in Amber, Stanford University Press, Stanford, CA, 1992.

Poinar Jr., G. O., Curčic, B. P. M., and Cokendolpher, J. C.: Arthropod phoresy involving pseudoscorpions in the past and present, Acta Arachnol., 47, 79-96, 1998.

Protescu, O.: Etude geologique et paleobiologique de l'ambre Roumain. Les inclusions organiques de l'ambre de Burzan I, Bul. Soc. Romane de Geol., 3, 1-46, 1937. 
Riquelme, F., Piedra-Jiménez, D. F., Córdova-Tabares, V., and Luna-Castro, B.: A new chernetid pseudoscorpion from the Miocene Chiapas - amber Lagerstätte, Mexico, Can. J. Earth Sci., 51, 902-908, 2014.

Ross, A. J.: Insects in amber, Geol. Today, 13, 24-28, 1997.

Savory, T.: On the names of the orders of Arachnida, Syst. Biol., 21, 122-125, 1972.

Schawaller, W.: Neue Pseudoskorpione aus dem Baltischen Bernstein der Stuttgarter Bernsteinsammlung (Arachnida: Pseudoscorpionidea), Stuttgarter Beitr. Naturk. (B), 42, 1-21, 1978.

Schawaller, W.: Erstnachweis tertiärer Pseudoskorpione (Chernetidae) in Dominikanischen Bernstein, Stuttgarter Beitr. Naturk. (B), 57, 1-20, 1980a.

Schawaller, W.: Fossile Chthoniidae in Dominikanischem Bernstein, mit phylogenetischen Anmerkungen (Stuttgarter Bernsteinsammlung: Arachnida, Pseudoscorpionidea), Stuttgarter Beitr. Naturk. (B), 63, 1-19, 1980 b.

Schawaller, W.: Cheiridiidae in Dominikanischem Bernstein, mit Anmerkungen zur morphologischen Variabilität (Stuttgarter Bernsteinsammlung: Arachnida, Pseudoscorpionidea), Stuttgarter Beitr. Naturk. (B), 75, 1-14, 1981a.

Schawaller, W.: Pseudoskorpione (Cheliferidae) phoretisch auf Käfern (Platypodidae) in Dominikanischen Bernstein (Stuttgarter Bernsteinsammlung: Pseudoscorpionidea und Coleoptera), Stuttgarter Beitr. Naturk. (B), 71, 1-17, 1981 b.

Schawaller, W.: Der erste Pseudoskorpion (Chernetidae) aus Mexicanischem Bernstein, Stuttgarter Beitr. Naturk. (B), 85, 1-9, 1982.

Schawaller, W.: The first Mesozoic pseudoscorpion, from Cretaceous Canadian amber, Palaeontology, 34, 971-976, 1991.

Schawaller, W., Shear, W. A., and Bonamo, P. M.: The first Paleozoic pseudoscorpions (Arachnida, Pseudoscorpionida), Am. Mus. Novit., 3009, 1-17, 1991.

Schlee, D.: Bernstein-Raritäten, Staatliches Museum für Natukunde, Stuttgart, 1980.

Schlee, D. and Glockner, W.: Bernstein, Stuttgarter Beitr. Naturk. (C), 8, 1-72, 1978.

Schlüter, T.: The East African copal - an almost forgotten fossiliferous resin, in: Current Research at the Department of Geology, edited by: Kohring, R. and Schlüter, T., Makarere University, Kampala, Uganda, Documenta Naturae, 77, 63-72, 1993.

Schmidt, A.-R., Kaulfuss, U., Borken, A., Busch, A., Conran, J., D’Haese, C., Engel, M. S., Harvey, M. S., Kerr, P., Kettunen, E., Kiecksee, A. P., Larivire, M.-C., Lengeling, F., Maraun, M., and Perrichot, V.: Amber inclusions from New Zealand, 9th European Palaeobotany-Palynology Conference, August 2014, Padoue, France: 246-248, 2014.

Schmitt, T.: Molecular biogeography of Europe: Pleistocene cycles and postglacial trends, Front. Zool., 4, 11, 2007.

Schumann, H. and Wendt, H.: Zur Kenntnis der tierischen Inklusen des Sächischen Bernsteins, Dtsch. entomol. Z., N.F., 36, 33-44, 1989.

Scudder, S. H.: Index to the known fossil insects of the world, including myriapods and arachnids, Bull. US Geol. Surv., 71, 7735,1891

Selden, P. A.: Fossil history of the arachnids, News. Brit. arachnol. Soc., 58, 4-6, 1990.
Selden, P. A.: Arthropoda (Aglaspidida, Pycnogonida and Chelicerata), in: The Fossil Record 2, edited by: Benton, M. J., Chapman \& Hall, London, 297-320, 1993a.

Selden, P. A.: Fossil arachnids - recent advances and future prospects, Mem. Qld. Mus., 33, 389-400, 1993b.

Selden, P. A. and Dunlop, J. A.: Fossil taxa and relationships of chelicerates, in: Arthropod Fossils and Phylogeny, edited by: Edgecombe, G., Columbia University Press, New York, 303331, 1998.

Selden, P. A. and Penney, D.: Fossil spiders, Biol. Rev., 85, 171206, 2010.

Selden, P. A., Dunlop, J. A., Giribet, G., Zhang, W., and Ren, D.: The oldest armoured harvestman (Arachnida: Opiliones: Laniatores), from Upper Cretaceous Myanmar amber, Cret. Res., 65, 206-212, 2016.

Sharma, P. P., Kaluziak, S. T., Pérez-Porro, A. R., Gonzaláez, V. L., Hormiga, G., Wheeler, W. C., and Giribet, G.: Phylogenomic interrogation of Arachnida reveals systemic conflicts in phylogenetic signal, Mol. Biol. Evol., 31, 2963-2984, 2014.

Shear, W. A., Schawaller, W., and Bonamo, P. M.: Record of Palaeozoic pseudoscorpions, Nature, 341, 527-529, 1989.

Shi, G.-H., Grimaldi, D. A., Harlow, G. E., Wang J., Yang, M.-C., Lei, W.-Y., Li, Q., and Li, X.-H.: Age constraints on Burmese amber based on U-Pb dating of zircons, Cret. Res., 37, 155-163, 2012.

Shultz, J. W.: A phylogenetic analysis of the arachnid orders based on morphological characters, Zool. J. Linn. Soc., 150, 221-265, 2007.

Spahr, U.: Ergänzungen und Berichtigungen zu R. Keilbachs Bibliographie und Liste der Bernsteinfossilien - Verschiedene Tiergruppen, ausgenommen Insecta und Araneae, Stuttgarter Beitr. Naturk. (B), 194, 1-77, 1993.

Stout, E. C., Beck, C. W., and Anderson, K. B.: Identification of rumanite (Romanian amber) as thermally altered succinate (Baltic amber), Phys. Chem. Minerals, 27, 665-678, 2000.

Suarez, S. E., Brookfield, M., Catlos, E. J., and Stöckli, D. F.: A U-Pb zircon age constraint on the oldest-recorded air-breathing land animal, PLoS ONE, 12, e0179262, https://doi.org/10.1371/journal.pone.0179262, 2017.

Subías, L. S. and Arillo, A.: Oribatid mite fossils from the Upper Devonian of South Mountain, New York and the Lower Carboniferous of County Antrim, Northern Ireland (Acariformes, Oribatida), Est. Mus. Cien. Nat. Alava, 17, 93-106, 2002.

Turienzo, P., Di Iorio, O., and Mahnert, V.: Global checklist of pseudoscorpions (Arachnida) found in birds' nests, Rev. suisse Zool., 117, 557-598, 2010.

Viehofen, A., Hartkopf-Fröder, C., and Friis, E. M.: Inflorescences and flowers of Mauldinia angustiloba sp. nov. (Lauraceae) from Middle Cretaceous karst infillings in the Rhenish Massif, Germany, Int. J. Plant Sci., 169, 871-889, 2008.

Wang, B., Rust, J., Engel, M. S., Szwedo, J., Dutta, S., Nel, A., Fan, Y., Meng, F., Shi, G., Jarzembowski, E. A., Wappler, T., Stebner, F., Fang, Y., Mao, L., Zheng, D., and Zhang, H.: A diverse palaeobiota in Early Eocene Fushun amber from China, Curr. Biol., 24, 1606-1610, 2014.

Weyenbergh Jr., H.: Notes sur quelques Insects du calcaire jurassique de la Bavière, Arch. Mus. Teyler, Haarlem, 3, 234-236, 1874. 
Weygoldt, P.: The Biology of Pseudoscorpions, Harvard University Press, Harvard, MA, 1969.

Whalley, P. E. S.: Neuroptera (Insecta) in amber from the Lower Cretaceous of Lebanon, Bull. Brit. Mus. Nat. Hist. (Geol.), 33, 157-164, 1980.

Wolfe, A., McKellar, R. C., Tappert, R., Sodhi, R. N. S., and Muehlenbachs, K.: Bitterfeld amber is not Baltic amber: Three geochemical tests and further constraints on the botanical affinities of succinite, Rev. Palaeobot. Palynol., 225, 21-32, 2016.

Wolfe, J. M., Daley, A. C., Legg, D. A., and Edgecombe, G. D.: Fossil calibrations for the arthropod Tree of Life, Earth-Sci. Rev., 160, 43-110, 2016.

Wood, H. W., Matzke, N. J., Gillespie, R. G., and Griswold, C. E.: Treating fossils as terminal taxa in divergence time estimation reveals ancient vicariance patterns in the palpimanoid spiders, Syst. Biol., 62, 264-284, 2012.
Woodward, H.: On the discovery of a new and very perfect Arachnide from the ironstone of the Dudley Coal-field, Geological Magazine, 8, 385-388, 1871.

Wu, R. J. C.: Secret of a lost world. Dominican amber and its inclusions, Self-Published, Santa Domingo, Dominican Republic, 1996.

Xia, F., Yang, G., Zhang, Q., and Shi, G.: Amber. Lives through Time and Space, Science Press, Beijing, 2015 (in Chinese with English preface). 